Artigo original

Hegemonia - Revista Eletrônica de Relações Internacionais do Centro Universitário Unieuro

ISSN: $1809-1261$

UNIEURO, Brasília, número 10, 2012, pp. 158-252.

Recebido em: 3/5/2012

Revisado em: $12 / 5 / 2012$

Aprovado em: 18/6/2012

\title{
DIREITO DE INTERNET: \\ ANÁlISE DO PROJETO DE LEI 2126/2011
}

CUSSI, DANIELA ${ }^{1}$

RESUMO: O presente trabalho tem como objeto a análise do projeto de lei denominado Marco Civil da Internet (PL 2126/2011), que se encontra em tramitação na Câmara dos Deputados e pretende regulamentar a utilização da internet, no Brasil. A pesquisa tem como escopo traçar, em linhas gerais, as mudanças e evoluções ocorridas na sociedade desde o advento da Internet, assim como, entender como a tutela dos direitos no âmbito virtual pode ser feita de forma efetiva tanto a nível nacional como internacional. A metodologia utilizada na pesquisa é teórico dedutiva, pois escrever sobre algo tão novo e polêmico como 0 Direito Cibernético exige que 0 tema seja amplamente pesquisado em livros, monografias, jornais, revistas, filmes, jurisprudências, doutrinas e demais fontes de informações. Tem como objetivo avaliar se o documento legal, em análise, realmente será eficaz, caso aprovado pelo Congresso Nacional, sem que haja a mitigação dos direitos garantidos constitucionalmente aos cidadãos. Ademais, pretende-se verificar se o projeto de lei está em harmonia com a legislação atualmente vigente referente ao Direito de internet, sem que prejudique o que já foi consolidado no âmbito do Direito virtual dentro de nosso ordenamento jurídico.

Palavras-chave: Direito de Internet; Projeto de Lei 2126/2011; Princípios Constitucionais; Eficácia da Lei.

1 Bacharel em Direito e Bibliotecária do Centro Universitário Unieuro. 
Artigo original

Hegemonia - Revista Eletrônica de Relações Internacionais do Centro Universitário Unieuro

ISSN: $1809-1261$

UNIEURO, Brasília, número 10, 2012, pp. 158-252.

ABSTRACT: The present piece of work aims the analysis of the bill called Internet Civil Mark (PL 2126/2011), which is in progress at the Federal House of representatives and intends to regulate the use of Internet in Brazil. The present research has as a scope to determine, in general, the changes and evolutions that have happened in society since the advent of Internet, as well as to understand how the tutorage of the rights in the virtual sphere can be produced in an effective way, either in a national level as well as international. The methodology used during this research is the deductive theory, for writing about something so incipient and controversial as the Cybernetic Law demands that the issue be vastly searched in books, monographs, newspapers, magazines, movies, jurisprudence, doctrines, and whatever sources of information. It has the goal of evaluating whether the legal document being analyzed is really effective, in case of been approved by the National House of Representatives, without having the mitigation of the constitutionally guaranteed rights to citizens. Furthermore, it is intended to verify whether such bill is in harmony with the legislation currently in effect related to the Internet Law, without harming what has already been consolidated within Virtual Law in our legal system.

Keywords: Cybernetic Law; Bill 2126/2011; Constitutional principles; Law efficiency.

\section{INTRODUÇÃO}

O presente trabalho busca fazer uma análise do projeto de lei 2126/2011 que tramita no Congresso Federal, a luz da Constituição de 1988, verificando o real impacto e eficácia que tal documento terá dentro do mundo jurídico e da sociedade, a nível interno. Para tanto, abordou-se a evolução do Direito e como este se adapta às mudanças sociais e tecnológicas que atingiram a sociedade nos últimos tempos e de como ele se comporta frente ao advento da internet e do mundo 
Artigo original

Hegemonia - Revista Eletrônica de Relações Internacionais do Centro Universitário Unieuro

ISSN: $1809-1261$

UNIEURO, Brasília, número 10, 2012, pp. 158-252.

globalizado.

A facilidade de troca de informações, assim como comercialização de produtos entre cidadãos de países diferentes, cria um novo tipo de relação jurídica, gerando vários tipos de questionamentos em relação a sua utilização. Como compatibilizar relações contratuais entre países que possuem legislações diferentes? Como são tratadas as questões que ferem a moral e os bons costumes quando se trata de culturas diversas? Qual o foro para elidir conflitos de interesses? Como fica o direito à privacidade? E a liberdade de expressão, é realmente ilimitada? Quem controla? Quem é o responsável civil? Estes são alguns dos vários questionamentos que continuam sem resposta e respaldo no mundo jurídico, enquanto a cada dia cresce o número de internautas, convivendo e porque não dizer colidindo interesses dentro desse universo.

O surgimento da Internet foi, sem dúvida alguma, uma ferramenta de grande importância para a globalização, já que desempenha um papel fundamental na comunicação e transmissão de informações entre os indivíduos ao redor do mundo. O uso dos recursos da informática no cotidiano dos lares e das empresas e a utilização da Internet como um dos principais meios de comunicação determinou a formação de uma nova sociedade, na qual o poder da informação passou a desempenhar um papel fundamental para qualquer indivíduo, e afetou a vida de milhões de pessoas.

O Direito, como disciplina jurídica das relações humanas, não pode esquivar-se de tais conseqüências, sendo, portanto, submetido a diversos questionamentos, os quais são a coluna vertebral desta 
Artigo original

Hegemonia - Revista Eletrônica de Relações Internacionais do Centro Universitário Unieuro

ISSN: $1809-1261$

UNIEURO, Brasília, número 10, 2012, pp. 158-252.

pesquisa que tem como objetivo analisar o projeto de lei proposto e as relações que ocorrem na Grande Rede, para que estas possam ser tuteladas sem que haja a mitigação de direitos fundamentais garantidos constitucionalmente.

Até o presente momento, a violação aos direitos no âmbito virtual vem sendo analisados com base na legislação, penal, civil e consumerista existentes em nosso ordenamento jurídico, o que muitas vezes não é suficiente devido à peculiaridade dos casos na seara global. Considerando que a expansão da Internet tomou proporções nunca antes imaginadas, faz-se necessária e urgente a criação de legislação própria e cuidadosamente proposta para que possa regular de forma eficaz as relações virtuais preservando direitos como a liberdade e privacidade. Por esse motivo é que a análise do projeto de lei 2126/2011 deve ser cuidadosa, mas ao mesmo tempo rápida, para que não nasça como uma lei morta devido à morosidade do Congresso Nacional e a agilidade da multiplicação de relações distintas que a cada dia surgem na rede.

Fato inegável é que a produção legislativa em relação ao direito virtual é inversamente proporcional ao crescimento de relações providas pela Internet, não é uma situação que ocorra somente no Brasil, mas até mesmo nas nações que já estão bem mais desenvolvidas na área da regulamentação da Internet, como é o caso dos Estados Unidos, que é o precursor da ferramenta.

Vários questionamentos surgem quando se observa a dimensão que a Internet tomou dentro do cotidiano de cada cidadão, não só do Brasil, mas de todas as nações. Deve-se lembrar que uma das maiores 
Artigo original

Hegemonia - Revista Eletrônica de Relações Internacionais do Centro Universitário Unieuro

ISSN: $1809-1261$

UNIEURO, Brasília, número 10, 2012, pp. 158-252.

fortunas da atualidade nasceu a partir de um crime virtual, o Facebook, rede de relacionamentos criada a partir da invasão do servidor de uma das mais conceituadas Universidades americanas, a Havard. Tal fato se tornou público, não por ter havido uma punição, mas pela popularidade que a rede de relacionamentos alcançou, em pouco tempo no mundo todo. A história da criação do Facebook foi contada em livro e filme, mas em nenhum deles é mencionado a intervenção do judiciário americano no sentindo de punir ou coibir a atuação dos hackers que criaram a rede de relacionamento. Muito pelo contrário, o papel do judiciário nessa história foi de tutelar a disputa pelos créditos advindos do Facebook, entre Mark Zuckerberg (mentor intelectual e hacker) e Eduardo Saverin (cofundador do site).

O Facebook então gerou uma grande fortuna obtida com base em vários crimes, dos quais podemos citar o furto e disseminação de informações, exposição não autorizada da intimidade e imagem dos alunos, dano moral e invasão de privacidade. Entretanto a única punição que houve, foi uma constrangedora advertência pelo Conselho acadêmico de Harvard e nada além. Este caso serve para ilustrar que não basta haver uma legislação para regular o direito de internet, é necessário que essa tutela seja eficaz. Quantas pessoas já não se sentiram lesadas em seu direito a intimidade e permaneceram sem amparo legal por parte do judiciário? O mais recente caso foi o da atriz Carolina Dieckmann, a qual teve seu computador invadido por hackers, que a chantagearam pedindo dinheiro para que fotos íntimas não fossem disponibilizadas em sites. Não fosse pela questão da extorsão, este seria mais um caso em que não haveria punição por falta de 
Artigo original

Hegemonia - Revista Eletrônica de Relações Internacionais do Centro Universitário Unieuro

ISSN: $1809-1261$

UNIEURO, Brasília, número 10, 2012, pp. 158-252.

amparo legal, visto que não há tipificação penal para furto de imagem e nem para disponibilização destas via internet. No caso em tela os responsáveis irão responder por extorsão, mas ainda assim fica a sensação de insegurança jurídica no que diz respeito a tutela do ofendido nas relações virtuais.

Existem vários aspectos que devem ser considerados com maior cuidado, por nossos legisladores como: a) hoje a internet é base da aldeia global, a qual compreende povos e culturas diferenciadas; b) a evasão da internet da área restrita acadêmica para o uso comum do povo; c) não houve em seus primórdios uma verdadeira preocupação legislativa em regular as situações que poderiam ocorrer com o advento da sociedade global criada pela propagação rede, dessa forma foi permitido que todo tipo de desrespeito e invasões fossem realizadas sem que houvesse um real controle; d) regular o uso da internet a nível nacional resolverá em parte os problemas provenientes do uso inadequado, mas como fazer com as relações que extrapolam as fronteiras de nosso país?

São muitas as perguntas que permeiam a questão, e a principal delas é: Será que, caso o projeto 2126/2011 seja convertido em lei, estará realmente apto a atingir plenamente a seu objetivo preservando os direitos já consagrados pela Constituição Federal de 1988, pacificar e normatizar o uso da Internet dentro do território brasileiro?

Em torno deste questionamento a pesquisa foi construída, tendo o propósito de discutir e chamar a atenção para essa questão, de extrema importância, que vem sendo tratada com descaso pelo poder legislativo, considerando os vários projetos de lei sobre direito virtual 
Artigo original

Hegemonia - Revista Eletrônica de Relações Internacionais do Centro Universitário Unieuro

ISSN: $1809-1261$

UNIEURO, Brasília, número 10, 2012, pp. 158-252.

ainda aguardando para serem deliberados.

\section{A INTERNET}

Com o escopo de contextualizar o atual momento vivido pela sociedade será abordado, neste capítulo, a criação da Internet, até seus aspectos técnicos de funcionamento para que o leitor possa entender, de forma lógica, os processos que ocorrem em rede no momento em que o usuário abre sua ferramenta de busca e acessa qualquer site na $W e b$.

Tais informações serão de grande valia no momento em que o projeto de lei $2126 / 2011$ for, posteriormente, analisado em seu caráter de aplicabilidade e constitucionalidade, objetos deste estudo.

\subsection{EVOLUÇÃO E HISTÓRICO}

A internet, na lição de James F. KUROSE, "é uma rede de computadores que interconecta milhares de dispositivos computacionais ao redor do mundo." ${ }^{2} \mathrm{~A}$ origem do desenvolvimento do que hoje é a Internet data da década de 60, mais especificamente no ano de 1969, nos Estados Unidos, durante o período conhecido como "Guerra Fria", com o objetivo de proteger as informações estratégicas

\section{2} p.2

KUROSE, James. F. Redes de computadores e a internet. São Paulo: Pearson, 2010. 
Artigo original

Hegemonia - Revista Eletrônica de Relações Internacionais do Centro Universitário Unieuro

ISSN: $1809-1261$

UNIEURO, Brasília, número 10, 2012, pp. 158-252.

daquela nação, em caso de um ataque a seus centros de inteligência. A internet recebia a esse tempo a denominação de ARPAnet, pois foi desenvolvida pela ARPA (Advanced Research and Projects Agency) e tinha como objetivo manter a comunicação entre as bases do exército, sendo assim, mesmo que o pentágono fosse atacado, as informações contidas em seus computadores não se perderiam.

Antes da ARPANET, já existia outra rede que ligava estes departamentos de pesquisa e as bases militares, mas como os EUA estavam em plena guerra fria, e toda a comunicação desta rede passava por um computador central que se encontrava no Pentágono, sua comunicação era extremamente vulnerável."3

Partindo daí a necessidade de criar um meio de proteção de dados e ao mesmo tempo de troca de informações ágil.

Quando do lançamento do primeiro Sputnik, em fins da década de 50, assustou os centros de alta tecnologia estadunidenses, a ARPA empreendeu inúmeras iniciativas ousadas, algumas das quais mudaram a história da tecnologia e anunciaram a chegada da Era da Informação em grande escala. Uma dessas estratégias, que desenvolvia um conceito criado por Paul Baran na Rand Corporation em 1960-4, foi criar um sistema de comunicação invulnerável a ataques nucleares. Com base na

3

BOGO, Kellen Cristina. A história da internet - como tudo começou, 2000. Disponível em: <http://kplus.cosmo.com.br/materia.asp?co=11\&rv=Vivencia> Acesso em: 14 de março de 2012. 
Artigo original

Hegemonia - Revista Eletrônica de Relações Internacionais do Centro Universitário Unieuro

ISSN: $1809-1261$

UNIEURO, Brasília, número 10, 2012, pp. 158-252.

tecnologia de comunicação da troca de pacotes, o sistema tornava a rede independente de centros de comando e controle, para que a mensagem procurasse suas próprias rotas ao longo da rede, sendo remontada para voltar a ter sentido coerente em qualquer ponto da rede. ${ }^{4}$

Para tanto, foi desenvolvido uma estrutura que desse o suporte necessário ao pleno funcionamento da comunicação entre os dispositivos ligados à ARPANET. Essa infraestrutura é denominada Backbone.

No contexto de redes de computadores, Backbone é o coração, a espinha dorsal da rede, designando o esquema de ligações centrais com a finalidade de demonstrar a topologia física, e lógica, de todos os dispositivos da rede para um melhor desempenho. Sua interligação era estruturada por baixo da terra, ou seja, não havia como encontrá-la de forma fácil e era praticamente indestrutível, não havendo um centro definido de processamento e transmissão de dados.

Em 1969, A ARPAnet estava aberta aos centros de pesquisa que colaboravam com o Departamento de Defesa dos EUA. Entretanto, os cientistas começaram a utilizar a infraestrutura para fins próprios, chegando a criar uma rede interna com interesse diverso da pesquisa militar. Dessa forma, com o crescimento da comunicação, tornou-se impossível separar a pesquisa voltada ao interesse militar das comunicações científicas e pessoais. Com isso, em 1983, houve a

4

CASTELLS, Manuel. A era da informação: economia, sociedade e cultura : A sociedade em Rede. São Paulo: Paz e Terra, 2005. p. 82 
Artigo original

Hegemonia - Revista Eletrônica de Relações Internacionais do Centro Universitário Unieuro

ISSN: $1809-1261$

UNIEURO, Brasília, número 10, 2012, pp. 158-252.

divisão entre ARPAnet, designada para fins científicos, e a MILNET, orientada diretamente para fins militares.

Sendo assim, tornou-se uma ferramenta de suma importância para o governo americano, que após o fim da ameaça da Guerra Fria, transformou-se em uma ferramenta pública, primeiramente permitindo o acesso aos cientistas e posteriormente aos acadêmicos e pesquisadores de Universidades.

É notório que o advento da criação da Internet somente foi possível ser concretizado graças aos esforços, de mentes brilhantes e inquietas das áreas, militar, científica e tecnológica. A partir de então, as redes começaram a multiplicar, sendo que no final da década de 70 já haviam 200 máquinas conectadas a ARPAnet, e assim foi se expandido.

Num segundo momento foi criada uma rede para interligar pesquisadores de instituições acadêmicas que não tinham acesso a ARPAnet.

Entretanto, foi na década de 90 que houve a explosão da Internet. Depois de 20 anos de funcionamento, a ARPAnet foi desativada em 28 de fevereiro de 1990. A partir de então, a rede foi tomando novos moldes, primeiramente de forma privada para só a posteriori tornar pública quando criada a World Wide Web, concebida na Europa em 1990, no Centre Européen poour Recherche Nuclearei (CERN), mais especificamente em Genebra. Essa interface mais simples trouxe a rede para dentro dos lares, escolas e empresas, conectando pessoas do mundo inteiro. O que possibilitou o que até aquele momento julgava-se praticamente impossível, a comunicação 
Artigo original

Hegemonia - Revista Eletrônica de Relações Internacionais do Centro Universitário Unieuro

ISSN: $1809-1261$

UNIEURO, Brasília, número 10, 2012, pp. 158-252.

em tempo real entre pessoas a longa distancia via computador.

A segunda metade da década de 1990 foi um período de tremendo crescimento e inovação para a Internet, com grandes corporações e milhares de novas empresas criando produtos e serviços para a Internet. O correio eletrônico pela Internet (e-mail) continuou a evoluir com leitores ricos em recursos provendo agendas de endereços, anexos, hot links e transporte multimídia. No final do milênio a Internet dava suporte a centenas de aplicações populares, entre elas quatro de enorme sucesso: e-mail, incluindo anexos e correio eletrônico com acesso pela Web; a Web, incluído navegação pela Web e comércio pela Internet; serviço de mensagem instantânea, com listas de contato, cujo pioneiro foi o ICQ; compartilhamento peer-to-peer de arquivos MP3, cujo pioneiro foi o Napster. ${ }^{5}$

Dessa forma, a World Wide Web, devido a seu caráter de "padrões universalmente aceitos para armazenar, recuperar, formatar e apresentar informações utilizando uma arquitetura cliente/servidor"6 de fácil acesso e utilização, tornou-se solo fértil para a sociedade em geral, principalmente para pessoas empreendedoras e visionárias, que não se conformando em utilizar a ferramenta somente como fonte de pesquisa e entretenimento, encontraram uma forma de fazer com que

5 p.49

KUROSE, James. F. Redes de computadores e a internet. São Paulo: Pearson, 2010.

6 p. 181

LAUDON, Kenneth C. Sistemas de informação gerenciais. São Paulo: Pearson, 2010. 
Artigo original

Hegemonia - Revista Eletrônica de Relações Internacionais do Centro Universitário Unieuro

ISSN: $1809-1261$

UNIEURO, Brasília, número 10, 2012, pp. 158-252.

o espaço virtual fosse fonte de renda e se empenharam em criar várias empresas com fins econômicos elevando o status da ferramenta à seara comercial. Podemos citar vários exemplos como: a Microsoft, Cisco, Yahoo, E-bay, Amazon, Google, dentre outros.

Outro aspecto que se deve considerar é o impacto que essa tecnologia causou na sociedade como um todo. De acordo com BARBOSA, "O acesso a informação vem sofrendo grandes transformações com a evolução tecnológica."7 Fato inegável quando se verifica que as tecnologias encurtaram distancias, disseminaram uma gama de informações preciosas à comunidade acadêmica, incrementaram o comércio e principalmente mudaram toda uma forma de vida social, criando um novo tipo de sociedade com hábitos, valores e costumes alterados pela facilidade proporcionada pela ferramenta.

O impacto das novas tecnologias, principalmente no campo da informática, levou a grandes transformações em todos os âmbitos da vida, com reflexos também para o Direito, que, segundo Miguel REALE, deve ser visto como fato, valor e norma. ${ }^{8}$

É comum, nos dias de hoje, ver adolescentes teclando freneticamente em frente a seus computadores, em bate-papos, jogos, redes de relacionamentos e demais aplicativos disponíveis na rede.

\section{7}

BARBOSA, Simone Diniz Junqueira. Interação humano-computador. Rio de Janeiro: Elsevier, 2010. p.3

8

LEAL, Sheila do Rocio Cercal Santos. Contratos eletrônicos: validade jurídica dos Contratos via Internet. São Paulo: Atlas, 2007. p.9 
Artigo original

Hegemonia - Revista Eletrônica de Relações Internacionais do Centro Universitário Unieuro

ISSN: $1809-1261$

UNIEURO, Brasília, número 10, 2012, pp. 158-252.

Hoje a internet passou a fazer parte do cotidiano de qualquer pessoa, independente do nível cultural ou social. Isso sem mencionar o impacto na educação do ser humano, pois não há mais como dissociar a busca na Internet, e a utilização desta para desenvolvimento de atividades pedagógicas e educativas.

O acesso a informação vem sofrendo grandes transformações com a evolução tecnológica. $\mathrm{Na}$ educação, por exemplo, um professor não pode mais considerar que ele e os livros são as únicas fontes de conhecimento disponíveis aos alunos. A Internet disponibiliza uma enorme quantidade de informação que os alunos podem acessar quando e onde desejarem. ${ }^{9}$

Qualquer um pode ter acesso à Internet, seja em casa, trabalho, escolas, Lan houses, cybercafés, enfim, a Web está no mundo todo criando um espaço virtual, onde as pessoas são livres para fazer o que bem entenderem, da forma como melhor the aprouver, em tempo real. Não há uma norma específica, ou mesmo um código de conduta que possa efetivamente regulamentar essas situações do mundo virtual e o que percebe é que essa amplitude de liberdade gera, muitas vezes, uma sensação de terra sem lei, de anarquia.

Toda essa evolução traz modificação profunda na sociedade e conseqüentemente para o ordenamento jurídico, que necessita se adaptar a essas mudanças para que possa tutelar o direito de forma eficaz e pacificar os conflitos provenientes desse novo tipo de relação 
Artigo original

Hegemonia - Revista Eletrônica de Relações Internacionais do Centro Universitário Unieuro

ISSN: $1809-1261$

UNIEURO, Brasília, número 10, 2012, pp. 158-252.

jurídica. Esse entendimento é reforçado nas palavras de Erica Bargallo, "A evolução das comunicações mediante o uso das redes de computadores traz consigo novas possibilidades de negociação, novas formas de relacionamentos, que têm conseqüências diretas no mundo jurídico". ${ }^{10}$

Como imaginar um espaço tão vasto sem regulamentação para uma pacífica convivência entre seus hospedeiros e usuários? Assim como o direito carece de segurança jurídica, essa nova Sociedade da Informação, como a denomina de forma perfeita CASTELLS, necessita de regulamentos para evitar conflitos desnecessários dentro do ambiente virtual.

Embora a rede tenha trazido uma revolução nas formas de comunicação da sociedade contemporânea, as conseqüências desta ainda são muito pouco previsíveis. O próprio funcionamento da rede não é plenamente conhecido por aqueles que a utilizam, e, mais ainda, são incipientes e exploratórias as formas de sua regulamentação. Mas uma coisa é certa: onde é utilizada, constitui-se em um domínio relativamente autônomo do Estado, tem caráter intrinsecamente multinacional e serve a múltiplas finalidades, desde o comércio de bens e serviços à troca de informações acadêmicas e científicas.

A tentativa de regulamentar um espaço destes $\square$ que produz, mesmo, um meio específico, o ciberespaço, anárquico, individualista, autônomo,

\section{0}

BARGALO, Erica Brandini. Contratos eletrônicos: contratos formados por meio de redes de computadores: peculiaridades jurídicas na formação do vinculo. São Paulo: Saraiva, 2001. p.2 
Artigo original

Hegemonia - Revista Eletrônica de Relações Internacionais do Centro Universitário Unieuro

ISSN: $1809-1261$

UNIEURO, Brasília, número 10, 2012, pp. 158-252.

com dimensões incontroláveis, em que os usuários se movem com enorme rapidez e se relacionam de forma profundamente igualitária $\square$ teria necessariamente de levar em consideração essas características, geradoras de uma multiplicidade de regras em constante reformulação, para atender os aspectos profundamente dinâmicos das interações ali atualizadas. ${ }^{11}$

Outra questão de extrema relevância é que por ser um espaço amplo, e, até o momento, impossível de fiscalização efetiva por parte do Estado, a Internet permite que pessoas civilmente incapazes utilizem de suas ferramentas, dessa forma, proporciona um espaço para que brincadeiras de péssimo gosto sejam feitas, ou até mesmo postagens infelizes que tem como objetivo, magoar, denegrir, enfim, expor algum desafeto. É o chamado cyberbulling, o qual ocorre com facilidade tamanha, que chega a ser uma afronta aos princípios éticos da sociedade, em páginas como Facebook, Orkut, Youtube, Blogs, dentre outras.

Basta procurar no Youtube por temas como briga, vandalismo, traição, dentre outros tantos, para que se tenha acesso a todo tipo de mazela social. Crianças marcam de se encontrar para brigar, documentam em vídeo e fazem o upload na rede, sem ter a menor noção que aquilo é crime de lesão corporal e que ao disponibilizar no sítio estão assumindo sua culpa. Como punir esses menores se a lei que deveria ser aplicada, por analogia, ao caso concreto exime o

\footnotetext{
11 p.16

CORREA, Gustavo Testa. Aspectos jurídicos da Internet. São Paulo: Saraiva, 2010.
} 
Artigo original

Hegemonia - Revista Eletrônica de Relações Internacionais do Centro Universitário Unieuro

ISSN: $1809-1261$

UNIEURO, Brasília, número 10, 2012, pp. 158-252.

menor da responsabilidade? Quem responderá pelo ato da agressão? Quem responderá pelo ato da exposição humilhante daquele que foi lesado física e moralmente? Os pais? Na maioria das situações os próprios genitores não fazem idéia de como a Internet funciona, o que dificulta ainda mais a vigilância sobre o comportamento dos jovens no mundo virtual.

Fora isso, inúmeros golpes são aplicados com o intuito de lesar os menos precavidos. Clonagem de senhas, furto em contas bancárias, contratos não cumpridos, agressões a honra, enfim, o rol de crimes virtuais é extenso. As violações às normas sociais de conduta são facilitadas neste espaço, por um aspecto até o momento sem solução: a impossibilidade de efetiva fiscalização.

O direito não só deve conhecer os meios de funcionamento da rede como prever a forma como a sociedade se comportará em relação ao advento dessa tecnologia. No entendimento de Patrícia Peck, "Toda mudança tecnológica é uma mudança social, comportamental, portanto jurídica"12 Da mesma forma, os legisladores devem o quanto antes se voltar para a questão virtual e regulamentar o direito neste âmbito se adaptando às mudanças sociais ocorridas na aldeia global.

\subsection{COMPOMENTES DA REDE DE COMPUTADORES}

Abordaremos agora alguns aspectos importantes em relação a

12

PECK, Patrícia apud ZANIOLO, Pedro Augusto. Crimes modernos: o impacto da tecnologia no Direito. Curitiba: Juruá, 2007. p.95 
Artigo original

Hegemonia - Revista Eletrônica de Relações Internacionais do Centro Universitário Unieuro

ISSN: $1809-1261$

UNIEURO, Brasília, número 10, 2012, pp. 158-252.

internet e sua estrutura, visto que, para se legislar é necessário, antes de mais nada, entender como funciona essa grande teia global.

A internet é uma rede de computadores que interconecta milhares de máquinas e dispositivos computacionais em diversas nações. Durante sua criação e até bem pouco tempo, esses dispositivos tecnológicos eram em sua maioria computadores de mesa, estações de trabalho e servidores de armazenamento e transmissão de dados. Com a evolução da tecnologia, esses dispositivos ganharam nova forma, como TVs, laptops, consoles para jogos, dispositivos móveis, dispositivos de sensoriamento remoto, automóveis, enfim, várias outras formas de aparelhos que estão sendo conectados à rede, os quais são denominados sistemas finais.

Sistemas finais são conectados entre si por enlaces, popularmente conhecidos como links, de comunicação e comutadores de pacotes. Esses enlaces, com a evolução da comunicação foram desenvolvidos diferentes meios físicos para os links podendo hoje ser classificados em links guiados e não guiados. A diferença entre os dois é bem simples: Os enlaces guiados possuem uma forma física palpável para a transmissão de dados, como por exemplo: cabos coaxiais, fios de cobre e fibras óticas. Já os não guiados, possuem o ar como meio de transmissão da informação, são as chamadas ondas de rádio, podemos citar como exemplos os satélites, as redes e a wireless.

Para que haja a transmissão de informações entre os usuários finais, é necessário equipamentos para que possa ser executada o que se denomina de computação por pacotes. Um comutador por pacotes tem a função primordial de encaminhar o pacote de informações a 
Artigo original

Hegemonia - Revista Eletrônica de Relações Internacionais do Centro Universitário Unieuro

ISSN: $1809-1261$

UNIEURO, Brasília, número 10, 2012, pp. 158-252.

seus destinos finais, ou seja, é este comutador que irá distribuir os pacotes que trafegam concomitantemente por toda a rede. Em uma analogia bem simplória, ele seria o entregador de correspondências que identifica o endereço e entrega a carta ao seu destinatário.

Como observamos até aqui, a internet é um sistema extremamente complicado que possui vários componentes como: sistemas finais, conexões entre os sistemas e meios físicos de enlace, sem os quais seria impossível seu funcionamento de forma ágil e eficaz como é feito hodiernamente. Para a internet funcionar é necessário a execução de várias atividades ou tarefas. Para que essas tarefas sejam efetuadas a contento, é melhor dividi-las em vários responsáveis para que a sua execução possa ser feita com qualidade. A essa divisão das funcionalidades denomina-se camada. Cada camada deve prover seu serviço realizando ações específicas dentro da camada e ao mesmo tempo utilizando os serviços da camada imediatamente inferior.

Sendo assim, para que haja o pleno funcionamento de toda a rede, essas camadas são organizadas com protocolos. Para cada protocolo há somente uma das camadas, e tem como função prover seu serviço, executando ações dentro da camada e, conforme explicado anteriormente, utilizando os serviços da camada diretamente abaixo dela.

É importante o conhecimento destes conceitos para que possa se entender a forma como a rede funciona no todo. Não é possível pensar em legislar sobre algo que não se conhece profundamente, aspectos simples como a função de um protocolo, de um provedor são de 
Artigo original

Hegemonia - Revista Eletrônica de Relações Internacionais do Centro Universitário Unieuro

ISSN: $1809-1261$

UNIEURO, Brasília, número 10, 2012, pp. 158-252.

extrema importância para que o legislativo atue de forma eficiente.

Enfim, por trás de todos esses aparatos tecnológicos que compõem a rede é ainda necessário um provedor, também conhecido como fornecedor de acesso, para que possamos utilizar todas as facilidades apresentadas pela internet. O provedor oferece o serviço de acesso à Internet, agregando a ele serviços relacionados como: email, hospedagem de home page, entre outros.

Após o fornecimento da liberação do acesso pelo provedor, ato de autenticação, é feita a permissão para transmitir ou compartilhar serviços ou informações pelas vias da maior rede do mundo. Qualquer tipo de transmissão ou solicitação de informações que se deseja efetivar por meio da internet deverá passar por equipamentos, por exemplo, roteadores, que possuem funções específicas para determinar qual a melhor rota, dentro da rede a ser seguida.

Para que essa melhor rota seja escolhida, o dispositivo precisa ter conhecimento de todos os demais interconectados na internet. Daí a importância do IP (Internet Protocol), pois é ele o responsável por identificar esses dispositivos. Geralmente, nos casos de crimes virtuais, o hacker é descoberto justamente por este número de IP.

O IP sendo responsável pelo endereçamento e encaminhamento tem intima ligação com a questão de endereçamento e conexão entre duas máquinas, mas também possibilitam a interligação de redes separadas. Dessa forma, para que o encaminhamento seja feito entre todos os nós pelos roteadores, é necessário que o endereçamento defina como os endereços IP, dos nós finais, são atribuídos e como as subredes são divididas e agrupadas, criando assim um verdadeiro 
Artigo original

Hegemonia - Revista Eletrônica de Relações Internacionais do Centro Universitário Unieuro

ISSN: $1809-1261$

UNIEURO, Brasília, número 10, 2012, pp. 158-252.

mapa do tráfego da informação.

É inegável que o aparato de infraestrutura existente por trás do funcionamento da internet é extremamente complexo. Entretanto, na prática, para o usuário leigo, o processo passa a nítida sensação de ser simples e livre, tornando o ambiente virtual em um verdadeiro campo anárquico, onde se pode tudo e não coíbe nada.

Se pararmos para observar com cuidado esse processamento de informações, que nasce de uma busca, ou envio de um dado, percebese que a ideia fundamental não é a de liberdade absoluta para o tráfego de informações. Por essa razão faz-se necessário entender o que realmente acontece ao transmitir qualquer tipo de informação pela rede virtual.

\subsection{A INTERNET NO BRASIL}

No Brasil esse advento tecnológico teve seu inicio na década de 90 com a RNP (Rede Nacional de Pesquisas) e tinha cunho acadêmico somente. Percebe-se nitidamente que o País se encontrava em grande desvantagem em relação ao desenvolvimento tecnológico dos Estados Unidos e Europa.

Mais especificamente, a RNP foi criada em setembro 1989 pelo Ministério da Ciência e Tecnologia (MCT), tinha como objetivo construir uma infra-estrutura de rede Internet nacional de âmbito acadêmico. O que coincide com o intuito inicial da abertura da Internet nos Estados Unidos, como visto anteriormente.

Em seu início era denominada de Rede Nacional de Pesquisa, 
Artigo original

Hegemonia - Revista Eletrônica de Relações Internacionais do Centro Universitário Unieuro

ISSN: $1809-1261$

UNIEURO, Brasília, número 10, 2012, pp. 158-252.

assim como o cunho acadêmico possui função de disseminar o uso de redes no país, por meio de seminários, palestras, montagem de repositórios temáticos e treinamentos, com o intuito de estimular a formação de seus futuros usuários e conscientizá-los da importância estratégica desta nova tecnologia para o país.

$\mathrm{Na}$ década de noventa houve a abertura da Internet para fins comerciais. A RNP então teve que redefinir seu papel, ampliando os serviços de acesso a todos os setores da sociedade.

Com essa reorientação de foco, a RNP ofereceu um importante apoio à consolidação da Internet comercial no Brasil. Foi criado o Centro de Informações Internet/BR para dar suporte no surgimento de provedores e usuários da rede. Mais de 3.000 questões relativas à Internet foram respondidas em seu primeiro ano de funcionamento. Inúmeras empresas fabricantes de bens de informática, tais como Compaq, Equitel, IBM, Philips etc., passaram a oferecer apoio concreto à RNP, fornecendo equipamentos, software e, mesmo, financiando atividades diretas do projeto. ${ }^{13}$

Dessa forma a Internet veio tomando corpo no Brasil, ganhando espaço e conhecimento dentro e fora do âmbito acadêmico. No final da década de 90 houve a assinatura de um convênio com o Ministério da Ciência e Tecnologia e Educação (MEC)

13

Histórico da RNP. Disponível em: <http://www.rnp.br/rnp/historico.html> Acesso em: 19/04/12 às $15 \mathrm{~h} 37$ 
Artigo original

Hegemonia - Revista Eletrônica de Relações Internacionais do Centro Universitário Unieuro

ISSN: $1809-1261$

UNIEURO, Brasília, número 10, 2012, pp. 158-252.

para que houvesse investimento e conseqüentemente a ampliação da rede que, a essa época, já ganhava notoriedade entre pesquisadores.

Assim, programas de incentivo e desenvolvimento foram executados e a Internet foi gradativamente ganhando popularidade, saindo da esfera acadêmica até atingir patamares nunca antes imaginados de acessos.

De acordo com pesquisa do IBOPE$^{14}$ (Instituto Brasileiro de Opinião Pública e Estatística), em dezembro de 2000 éramos cerca de 4,9 milhões de internautas. Este número cresceu de forma que em 2011 esta população chegou ao patamar de 38,2 milhões de pessoas com acesso a Internet, demonstrando, em dados, o impacto real desta ferramenta dentro da sociedade brasileira.

O ciberespaço é tão povoado quanto o físico, repleto de transações sociais e comerciais, desacordos e delitos. Os crimes incluem: extorsão, estelionato, vandalismo, jogos trapaceiros, fraude, ataques a sistemas de tráfego aéreo, invasão de privacidade, difamação, espionagem, pedofilia, apologia a crimes hediondos, etc. Antigos delitos com nova roupagem despontam no ciberespaço preocupando os internautas brasileiros que acabam por expor informações na Internet.

...

Um desafio em toda a discussão sobre o Marco Civil da Internet é como estabelecer regras quanto à utilização do ciberespaço, sem prejudicar questões

14

PAINEL IBOPE NET/RATINGS. Disponível em: < http://www.cetic.br/usuarios/ibope/tab02-01-cons.htm> Acesso em: 19/04/12 às 17h11 
Artigo original

Hegemonia - Revista Eletrônica de Relações Internacionais do Centro Universitário Unieuro

ISSN: $1809-1261$

UNIEURO, Brasília, número 10, 2012, pp. 158-252.

de avanços econômicos (e-commerce) e a liberdade de expressão. Conteúdos publicados na Internet não necessitam de autorização prévia, ou seja, qualquer indivíduo pode difundir qualquer informação. Em razão da liberdade de expressão e do fluxo de informações, a internet atua como transformadora social, econômica, cultural e política. ${ }^{15}$

O que fica claro, por tudo exposto neste capítulo é que a Internet vem se desenvolvendo em grande velocidade, fato este perceptível não somente pela mudança dos requisitos técnicos ou do público alvo, mas a mudança comportamental de toda a sociedade global. Entretanto, outro fator que salta aos olhos é que infelizmente, até o presente momento, o legislativo brasileiro não se preocupou suficientemente em regular essas relações advindas do mundo virtual, considerando os vários projetos de lei que estão parados no Congresso Nacional aguardando para serem votados.

15

ARAÚJO, Aisla Neilia de. Análise do marco civil da internet. Jus Navigandi, Teresina, ano 17, n.3208, 13/abr/2012. Disponível em: <http://jus.com.br/revista/texto/21474. Acesso em: 23 abr. 2012 
Artigo original

Hegemonia - Revista Eletrônica de Relações Internacionais do Centro Universitário Unieuro

ISSN: $1809-1261$

UNIEURO, Brasília, número 10, 2012, pp. 158-252.

\section{PRINCÍPIOS, CONSTITUIÇÃO E DIREITO}

Neste capítulo será analisada a Constituição e os princípios que são a base fundamental de qualquer legislação produzida em nossa pátria. Este assunto serve como base deste trabalho, visto que a discussão proposta é justamente se o Projeto de lei em análise realmente está de acordo com a Constituição ou se esta será uma lei que já nascerá com vicio em sua Constitucionalidade.

Cabe ainda esclarecer que não serão analisados todos os princípios que norteiam o sistema jurídico de nossa Nação, mas somente aqueles que tenham efetiva pertinência com o tema em discussão.

\subsection{PRINCÍPIOS E CONSTITUIÇÃO}

Princípio, para o Direito é aquilo que dá fundamento a uma norma, pois são os princípios que devem nortear o comportamento ético social, assim como, ser o alicerce para que o legislador defina e construa seus projetos de lei. É inegável sua importância não só para o Direito, mas para toda a sociedade como forma de conduta éticosocial.

Reforçando esta idéia encontra-se, no Dicionário Michaelis, a definição da palavra Princípio: 
Artigo original

Hegemonia - Revista Eletrônica de Relações Internacionais do Centro Universitário Unieuro

ISSN: $1809-1261$

UNIEURO, Brasília, número 10, 2012, pp. 158-252.

1. Momento em que uma coisa tem origem; começo. 2. Causa primária; razão, base. 3. Momento em que se faz alguma coisa pela primeira vez. 4. Regra, lei, preceito. 5. Ditame moral, sentença, máxima. 6. Teoria. 7. Quím. e Farm. Substância química que figura numa mistura. S. m. pl. 1. Os antecedentes. 2. As primeiras épocas da vida. 3. Doutrinas fundamentais ou opiniões predominantes $^{16}$

A análise da palavra já traz em seu bojo a sua importância para o direito, visto que se entende o princípio como uma norma originária que serve de alicerce para a efetiva atuação ética dentro do corpo social. Dessa forma, os princípios são, dentre as fontes do Direito, a mais relevante e de maior importância quando houver colisão de entendimentos, direitos ou até mesmo lacunas da lei. Reforçando este entendimento, Rizatto Nunez, em brilhante explanação sobre o tema, diz que:

Os princípios são, dentre as formulações deônticas de todo sistema ético jurídico, os mais importantes a ser considerados não só pelo aplicador do Direito mas também por todos aqueles que, de alguma forma, ao sistema jurídico se dirijam. Assim, estudantes, professores, cientistas, operadores do direito $\square$ advogados, juízes, promotores públicos etc. $\square$ todo têm de, em primeiro lugar, levar em consideração os princípios norteadores de todas as demais normas jurídicas existentes.

Nenhuma interpretação será bem feita se for 
Artigo original

Hegemonia - Revista Eletrônica de Relações Internacionais do Centro Universitário Unieuro

ISSN: $1809-1261$

UNIEURO, Brasília, número 10, 2012, pp. 158-252.

desprezado um princípio. É que ele, como estrela máxima do universo ético-jurídico, vai sempre influir no conteúdo e alcance de todas as normas. ${ }^{17}$

Dessa forma, é impossível desvincular o processo legislativo da aplicabilidade dos princípios gerais do Direito, principalmente dos Princípios Constitucionais, que devem ser observados para que a lei possa ter real eficácia dentro do ordenamento jurídico. Caso exista incompatibilidade entre a lei e a Constituição, ocorrerá a insegurança jurídica e tal conflito deverá ser resolvido com base na analogia e nos princípios, sendo assim, é óbvio que desde sua essência, deverá haver a observação cuidadosa destes, que são alicerces do Direito. Feito isso não há que se falar em conflito entre leis, e muito menos em insegurança jurídica, atual chaga do sistema jurídico.

A Constituição Federal traz em seu bojo vários princípios que tem aplicação direta e imediata, e são, no entendimento de Rizzatto Nunes, "o ponto mais importante do sistema normativo"18. Deve-ser ter a clara ideia de que os princípios são o alicerce de todo arcabouço jurídico e a inobservância a estes prejudica todo o sistema jurídico, pois irá gerar a contradição de julgados, os conflitos de interesses e inevitavelmente a discussão da matéria nas cortes superiores.

Há muita divergência na doutrina sobre o que e

17 2008. p.181-182.

NUNES, Rizzatto. Manual de introdução ao estudo do direito. São Paulo: Saraiva, 18

lbid., p.188. 
Artigo original

Hegemonia - Revista Eletrônica de Relações Internacionais do Centro Universitário Unieuro

ISSN: $1809-1261$

UNIEURO, Brasília, número 10, 2012, pp. 158-252.

quais seriam os "princípios gerais do direito". Sem entrar na controvérsia, podemos afirmar serem os que inspiram e dão embasamento à criação de toda e qualquer norma, inclusive e especialmente a Constituição, bem como os valores sociais que afetam o sistema e dirigem sua finalidade. São exemplos dos princípios gerais do Direito no Brasil: a Justiça, a dignidade do homem, a isonomia, a anterioridade para fins de cobrança de impostos, o sistema republicano, etc. ${ }^{19}$

Percebe-se então que o Legislativo ao cumprir sua função está deixando a desejar em relação ao teor jurídico das leis que são aprovadas. Este fato torna-se notório visto o grande número de ações de inconstitucionalidade (ADIs) que tramitam, ou já tramitaram, no Supremo Tribunal Federal $\square$ guardião da Constituição e por conseqüência de seus princípios $\square$ fazendo com que aquela corte trabalhe incessantemente para corrigir a forma como a lei deve ser entendida e conseqüentemente aplicada. Este fato acaba por obrigar que o Judiciário atue como Legislativo de forma atípica, o que não é o adequado, visto que pelo Princípio da separação dos poderes, cada um tem funções típicas específicas e definidas na Carta Magna.

Entretanto, apesar de não ser adequado é necessário para manter o equilíbrio conforme dispõe o sistema de freios e contrapesos. 
Artigo original

Hegemonia - Revista Eletrônica de Relações Internacionais do Centro Universitário Unieuro

ISSN: $1809-1261$

UNIEURO, Brasília, número 10, 2012, pp. 158-252.

Então se conclui que quando um dos poderes não cumpre a sua função de forma adequada acaba por prejudicar o trabalho dos demais poderes e ao invés de pacificar a sociedade acaba por gerar a sensação de insegurança jurídica. Dessa forma o judiciário fica sobrecarregado em suas atividades devido a obscuridade e lacuna das normas que já nascem inválidas, mas que mesmo assim, até que o Supremo Tribunal Federal se pronuncie quanto a Constitucionalidade, produzem efeitos no mundo jurídico. Essa informação encontra respaldo no texto de Rizzatto Nunes, in verbis:

É possível que o Poder Legislativo aprove uma lei inconstitucional? E que é publicada oficialmente (posta em vigor) após o sancionamento (aprovação) do Poder Executivo?

A resposta a todas essas questões é afirmativa. Não só é possível como, no Brasil, já foram aprovadas e postas em vigor várias normas jurídicas ilegais e inconstitucionais.

Um exemplo muito conhecido de todos: as normas jurídicas do Plano Collor, que, aliás, é um caso lapidar de hipótese de invalidade. [...]

[...] A conclusão, portanto, é a de que, apesar de inválida, a norma jurídica pode ser eficaz e incidir concretamente, pelo menos até que o Poder Judiciário impeça sua eficácia ou mesmo até que o Poder Legislativo a revogue.[...]

[...] Infelizmente, temos de concluir este item deixando consignado que são já muitas as leis inconstitucionais aprovadas e postas em vigor no Brasil. 20 
Artigo original

Hegemonia - Revista Eletrônica de Relações Internacionais do Centro Universitário Unieuro

ISSN: $1809-1261$

UNIEURO, Brasília, número 10, 2012, pp. 158-252.

Percebe-se claramente que, dentro do processo legislativo algo não ocorre da forma prevista pelo Constituinte em sua essência, existe uma falha na concepção da norma que a invalida antes mesmo de sua promulgação. O problema é que não há uma efetiva observância nem à Constituição nem aos princípios que a alicerçaram por parte do Legislador que cria leis de acordo com o interesse do Congresso sem o devido cuidado em relação aos preceitos constitucionais. Sem interesse do Congresso, pois os projetos que não são interessantes aos parlamentares levam longo tempo para que o processo legislativo seja finalizado.

Prova deste fato são os vários projetos sobre Direito de Internet, que estão parados nas casas legislativas. Dessa forma considera-se que o que talvez seja urgente para a sociedade, não seja urgente para os parlamentares que discutem, discutem, levam anos e anos para concluir a aprovação de uma lei e no final ainda o fazem de forma a publicá-la com lacunas, inconstitucionalidades, ou qualquer outro tipo de imperfeição, que levará o documento a ser questionado no judiciário.

\subsection{Direito e a Internet}

Tarefa árdua, nos dias atuais, é dissociar o cotidiano das relações virtuais. A sociedade tornou-se completamente dependente da Internet, o que justifica o aumento de proporções assustadoras de Internautas que passam parte de seu dia conectado à rede. Seja por meio de computadores, telefones ou qualquer outro meio tecnológico, 
Artigo original

Hegemonia - Revista Eletrônica de Relações Internacionais do Centro Universitário Unieuro

ISSN: $1809-1261$

UNIEURO, Brasília, número 10, 2012, pp. 158-252.

a verdade é que boa parte da população se mantém em rede praticamente 24 horas por dia. Até mesmo as pessoas de baixa renda que não possuem recursos financeiros, para possuírem computador pessoal e internet, procuram meios de acessar a rede, seja em lan houses ou em ambientes acadêmicos, todos querem fazer parte dessa nova sociedade global. Tal fato caracteriza uma mudança comportamental em relação a comunicação e a disseminação da informação que atualmente é extremamente veloz.

O volume de informações disponibilizadas a cada minuto pela Internet é imensurável, todos produzem e publicam aquilo que thes aprouver e é essa liberdade total de expressão que muitas vezes fere o direito do próximo, pela falta de cuidado, de zelo, com que é tratado conteúdo disponibilizado na rede mundial. É nesse contexto que o Direito necessita urgentemente ser pensado e tutelado pelos legisladores, pois utilizando aqui do brocardo "o seu direito termina aonde começa o meu", é perceptível que vários conflitos surgem por mera inobservância dos princípios éticos e morais que deveriam conduzir a sociedade.

Embora a rede tenha trazido uma revolução nas formas de comunicação da sociedade contemporânea, as conseqüências desta ainda são pouco previsíveis. O próprio funcionamento da rede não é plenamente conhecido por aqueles que a utilizam, e, mais ainda, ainda são incipientes e exploratórias as formas de sua regulamentação. Mas uma coisa é certa: onde é utilizada, constitui-se em um domínio relativamente autônomo do Estado, tem caráter intrinsecamente multinacional e serve a 
Artigo original

Hegemonia - Revista Eletrônica de Relações Internacionais do Centro Universitário Unieuro

ISSN: $1809-1261$

UNIEURO, Brasília, número 10, 2012, pp. 158-252.

múltiplas finalidades, desde o comércio de bens e serviços à troca de informações acadêmicas e científicas. ${ }^{21}$

Fica claramente definido que, neste contexto, existem dois direitos em colisão, o direito da liberdade de expressão e os direitos relativos a pessoa, como privacidade e honra.

O ambiente virtual, apesar de fazer parte da vida moderna e passar a sensação de solidez de procedimentos ainda está em processo de evolução e certamente continuará se modificando com o passar dos anos. Os usuários da ferramenta a cada dia descobrem novas formas de utilizá-la, seja para relações contratuais, pesquisa de informações, contato com outras pessoas, compras, ou como melhor Ihe aprouver. Todos os dias um novo aplicativo passa a fazer parte da vida dos internautas sempre buscando a agilidade da troca de informações.

Há bem pouco tempo, para se ter acesso as manchetes de jornais era necessário que o cidadão se dirigisse a banca de jornal e comprasse os exemplares que the eram desejados. Hoje, após a invenção do Twitter, este mesmo cidadão precisa somente ter um celular para que possa acessar todo o seu conteúdo de interesse em tempo real.

Dessa forma, com o advento da Internet, a informação ganhou velocidade, mas ao mesmo tempo volatilidade. Da mesma forma em que se disponibilizam facilmente informações no ambiente virtual,

\footnotetext{
21 p.16

CORREA, Gustavo Testa. Aspectos jurídicos da Internet. São Paulo: Saraiva, 2010.
} 
Artigo original

Hegemonia - Revista Eletrônica de Relações Internacionais do Centro Universitário Unieuro

ISSN: $1809-1261$

UNIEURO, Brasília, número 10, 2012, pp. 158-252.

essas informações também se perdem com grande facilidade dentro do enorme número de atualizações diárias. Sendo assim, é fácil perceber que a informação realmente tomou um aspecto volátil, e nem sempre será possível mantê-la. Esta é uma situação de certa forma complicada para o operador do Direito, pois a informação não é permanente. Ofensas à outrem podem ser disponibilizadas e posteriormente ocultadas, impedindo dessa forma que o Estado tenha meios de provas para tutelar o direito do ofendido.

O mesmo ocorre nas questões que envolvem o meio acadêmico, trabalhos, artigos, teses, monografia, enfim, produções cientificas muitas vezes são utilizadas em obras e ao se buscar por aquela citação novamente já não se encontram mais disponíveis as informações. Isso sem mencionar a questão do plágio, pois após a entrada da internet no meio acadêmico muitos se utilizam do patrimônio intelectual de outrem como se a ele pertencesse. Questão extremamente delicada, a qual não será abordada neste trabalho e figura apenas como modelo exemplificativo.

Interessante refletir sobre essa volatilidade da informação que somada a falta de um documento legal, realmente efetivo para tutelar as relações virtuais, e ao desconhecimento do aplicador do direito sobre o funcionamento e limites da Internet, causam a sensação de insegurança para a sociedade. Pois, justamente estes fatos têm gerado conflitos dentro do próprio judiciário. As decisões sobre a matéria são contraditórias e sem fundamento jurídico específico, devendo o magistrado se utilizar de todas as fontes do direito, já que não há lei específica. 
Artigo original

Hegemonia - Revista Eletrônica de Relações Internacionais do Centro Universitário Unieuro

ISSN: $1809-1261$

UNIEURO, Brasília, número 10, 2012, pp. 158-252.

Para o poder Judiciário, a ausência de definição legal específica, em face da realidade diversificada das relações virtuais, tem gerado decisões judiciais conflitantes, e mesmo contraditórias. Não raro, controvérsias simples sobre responsabilidade civil obtêm respostas que, embora direcionadas a assegurar a devida reparação de direitos individuais, podem, em razão das peculiaridades da Internet, colocar em risco as garantias constitucionais de privacidade e liberdade de expressão de toda a sociedade. ${ }^{22}$

Esse entendimento é reforçado pela doutrina de Gustavo Testa Correa quando menciona que:

Da mesma forma que no passado as linhas férreas eram responsáveis pela distribuição de uma vasta gama de materiais e informações, sendo assim alvo de inúmeras situações de cunho criminal, a Grande Estrada da Informação também é alvo de inúmeras atividades, desde sociais até criminais. Todas as questões relativas à Internet possuem um denominador comum, o desconhecimento gerando insegurança.

A desinformação se combate com a educação. Será através do desenvolvimento de cursos ultimando o aprimoramento do conhecimento técnico sobre a Rede, e outros tipos de tecnologia, que nossos juízes, advogados, promotores, delegados, etc. passarão a apreciar a matéria sem decisões ou

22

BRASIL. Projeto de Lei 2126/2011: estabelece princípios, garantias, direitos e deveres
para 0 uso da Internet no Brasil. p.8 Disponível em: <http://www.camara.gov.br/proposicoesWeb/fichadetramitacao?id Proposicao $=517255>$ 
Artigo original

Hegemonia - Revista Eletrônica de Relações Internacionais do Centro Universitário Unieuro

ISSN: $1809-1261$

UNIEURO, Brasília, número 10, 2012, pp. 158-252.

argumentos "vazios", inexpressivos e sem fundamento, culminando na melhoria da imagem da justiça. ${ }^{23}$

Apesar dos esforços da justiça em tutelar os direitos na seara virtual, a prestação jurisdicional não consegue ser realmente efetiva devido ao despreparo do julgador, dos operadores do direito e principalmente pela falta de normas regulamentadoras da matéria.

Existem em tramitação, há mais de quinze anos, vários projetos de lei que visam regular o ambiente virtual, porém, nenhum chegou a ser deliberado e convertido em lei.

A verdade é que a Internet mudou a estrutura comunicacional humana. A luta entre sociedade civil, economia, e Estado, pelo espaço público que antes acontecia na mídia, como dito anteriormente, mudou de lugar, e seus sujeitos, de posições. Hoje o ciberespaço compõe o espaço público e seus sujeitos são todos aqueles que tenham um computador ou celular com acesso à Internet. Cada novo internauta pode ser produtor ou emissor de informações e reorganizar por conta própria parte da conectividade global. ${ }^{24}$

Essas questões deveriam permear o pensamento do legislador no momento em que o projeto de lei irá ser delineado. Para que a

\section{3}

CORREA, Gustavo Testa. Op. Cit. p.131

24

OLIVEIRA, Régis Fernandes de. Liberdade de expressão e Internet. Revista de Direito das Comunicações, São Paulo, vol. 4, Jul. 2011. p.30 
Artigo original

Hegemonia - Revista Eletrônica de Relações Internacionais do Centro Universitário Unieuro

ISSN: $1809-1261$

UNIEURO, Brasília, número 10, 2012, pp. 158-252.

tutela do Estado seja realmente eficaz, devem-se ter leis bem elaboradas. De nada adianta uma norma que ao nascer para o ordenamento jurídico já está eivada de vício ou inconstitucionalidade. Seus efeitos serão temporários e ao ser julgada no Supremo Tribunal Federal terá sua eficácia mitigada.

O espaço virtual é um ambiente novo, repleto de características e peculiaridades muito próprias, motivo pelo qual deve ser entendido e cuidadosamente avaliado pelo legislador. Dessa forma, ao propor um projeto de lei possa esta atender aos anseios da sociedade, assim como os processos dinâmicos pertencentes à rede mundial. Tal idéia encontra respaldo na doutrina de Gustavo Testa Correa, quando diz:

A tentativa de regulamentar um espaço destes $\square$ que produz, mesmo, um meio específico, o ciberespaço, anárquico, individualista, autônomo, com dimensões incontroláveis, em que os usuários se movem com enorme rapidez e se relacionam de forma profundamente igualitária $\square$ teria necessariamente de levar em consideração essas características, geradoras de uma multiplicidade de regras em constante reformulação, para atender aos aspectos profundamente dinâmicos das interações ali atualizadas. ${ }^{25}$

Atualmente, por falta da legislação específica, resta ao julgador utilizar da hermenêutica e analogia para tutelar os direitos em relação a matéria, o que gera o conflito entre os julgados de diferentes tribunais, pois cada magistrado entende conforme sua experiência de

25

CORREA, Gustavo Testa. Op. Cit., p.16 
Artigo original

Hegemonia - Revista Eletrônica de Relações Internacionais do Centro Universitário Unieuro

ISSN: $1809-1261$

UNIEURO, Brasília, número 10, 2012, pp. 158-252.

vida, seus conhecimentos, suas crenças, sua região e decide com base somente nestes critérios.

Interessante comentar o entendimento de SANTOLIM, que acreditava ser possível tutelar as questões relacionadas com a Informática sem o respaldo de legislação específica, in verbis: "Vê-se que as fontes tradicionais do direito suportam as modificações trazidas pela moderna tecnologia informática, bastando que se use a hermenêutica com todas as suas possibilidades." 26 Tal entendimento, faz sentido ao analisarmos o contexto do momento em que a obra referenciada foi escrita, percebe-se então que em 1995, ainda era possível uma tutela eficaz sem uma lei que oferecesse suporte. Tal posiciona corrobora com a ideia de que o crescimento da Internet e a expansão do âmbito das tecnologias tiveram efeito direto sobre o Direito e a sua tutela. Direito este que o legislativo brasileiro ainda não conseguiu conferir documento legal para protegê-lo.

\section{PROJETO DE LEI 2126/2011}

Neste momento será apresentado o projeto de lei 2126/2011, sendo analisado capítulo à capítulo, assim como, serão feitas as devidas reflexões sobre o conteúdo proposto e sua eficácia, caso venha a ser convertido em lei, objeto da pesquisa.

\section{6}

SANTOLIM, César Viterbo Matos. Formação e eficácia probatória dos contratos por computador. São Paulo: Saraiva, 1995. p.41 
Artigo original

Hegemonia - Revista Eletrônica de Relações Internacionais do Centro Universitário Unieuro

ISSN: $1809-1261$

UNIEURO, Brasília, número 10, 2012, pp. 158-252.

\subsection{MARCO CIVIL DA INTERNET}

Conforme dito, nas últimas décadas vários projetos de lei tramitaram pelo Congresso Nacional com o intuito de regular questões especificas em relação a rede mundial de computadores, entretanto, poucos projetos foram convertidos em lei e passaram a realmente operar no mundo jurídico.

A falta de regramento legal sobre o uso da Internet no país gera enorme insegurança jurídica e dificulta o exercício de direitos fundamentais relacionados ao seu uso, cujos limites permanecem indefinidos e a tutela necessita de instrumentos específicos. Além disso, a falta de previsibilidade desmotiva investimentos na prestação de serviços on-line, restringindo a inovação e o empreendedorismo. $E$, ainda, sem regulamentação, nada impede que conglomerados de mídia

imponham barreiras tecnológicas de modo a concentrar a infraestrutura de acesso, conteúdo e monitoramento, restringindo a liberdade da rede. ${ }^{27}$

Hodiernamente, o que se obtém, são decisões nem sempre consonantes por parte do judiciário, justamente por haver essa lacuna dentro do direito. Tal fato, gera a premente necessidade da criação de um documento legal, realmente eficaz, que tutele as discussões acerca do âmbito virtual e traga maior segurança jurídica para os usuários da

27

OLIVEIRA, Régis Fernandes de. Liberdade de expressão e Internet. In: Revista de Direito das Comunicações, vol. 4, Jul. 2011. p.33 
Artigo original

Hegemonia - Revista Eletrônica de Relações Internacionais do Centro Universitário Unieuro

ISSN: $1809-1261$

UNIEURO, Brasília, número 10, 2012, pp. 158-252.

rede. Partindo desse pressuposto, surgiu por iniciativa do Ministério da Justiça e da FGV a idéia de discutir o projeto de lei pela própria Internet, de forma democrática onde o cidadão poderia opinar sobre a proposta a ser levada ao Congresso.

Uma proposta de anteprojeto de lei para regular a rede só poderia mesmo ser construída na própria rede. Assim, a Secretaria de Assuntos Legislativos do Ministério da Justiça (SAL-MJ) e o Centro de Tecnologia e Sociedade da Fundação Getulio Vargas (CTS-FGV) criaram uma plataforma no site Cultura Digital (http://cultura digital.BR/marcocivil/) para receber comentários sobre a iniciativa.

O processo de consulta pública foi dividido em duas fases. Na primeira, que teve início em outubro de 2009 e durou pouco mais de 45 dias, foi submetido à apreciação da sociedade um texto que continha os princípios gerais para a regulação da rede. Os participantes podiam detalhar esses princípios e propor novos temas a serem abarcados em uma futura legislação.

Durante essa primeira fase, foram recebidos mais de oitocentos comentários, que foram sistematizados e traduziram-se no texto do anteprojeto posto em consulta pública na plataforma on-line por, inicialmente, mais 45 dias. Atendendo a pedidos diversos, essa segunda etapa foi prorrogada por uma semana, encerrando-se em 30 de maio de 2010.

$\mathrm{Na}$ última fase, houve aproximadamente 1.200 comentários ao texto. Além de indivíduos e organizações da sociedade civil, participaram também empresas e associações ligadas à indústria de conteúdo, tanto nacionais como estrangeiras, o que aumentou a diversidade de opiniões e, ao final, fez crescer a responsabilidade na compilação e na 
Artigo original

Hegemonia - Revista Eletrônica de Relações Internacionais do Centro Universitário Unieuro

ISSN: $1809-1261$

UNIEURO, Brasília, número 10, 2012, pp. 158-252.

organização dos pontos de vista expostos durante o processo.

...

Com o término do debate público, coube a equipe do marco civil, reunindo representantes da SAL-MJ e do CTS/FGV, compilar todos os comentários, identificar as opiniões prevalecentes e fazer as alterações porventura devidas para, finalmente, apresentar à comunidade 0 texto a ser encaminhado ao Congresso Nacional. ${ }^{28}$

Essa metodologia de consulta à opinião pública teve o intuito de "reforçar o caráter social e democrático a ser atribuído à Internet."29 Podendo assim, ser amplamente discutido, pelos maiores interessados, que são os cidadãos, o Marco Civil da Internet, tornou-se um projeto de lei essencialmente democrático que busca estabelecer princípios, garantias, direitos e deveres para o uso da Internet no Brasil.

O objetivo do projeto de elaboração colaborativa do Marco Civil era elaborar um anteprojeto de lei que pudesse refletir, em termos legais, as efetivas demandas sociais pertinentes ao uso da Internet no Brasil, consideradas pela perspectiva da garantia das novas liberdades permitidas pelo advento da

\section{8}

SOUZA, Carlos Affonso Pereira de; MACIEL, Marília; FRANCISCO, Pedro Augusto. Marco Civil da Internet: uma questão de princípio. In: Revista poliTICs, n.7, Ago. 2010, p.68-69. Disponível

em:

<http://www.politics.org.br/sites/default/files/poliTICS_n07_souza_maciel_francisco.pdf> Acesso em: 23 abril 2012

29

ARAÚJO, Aisla Neilia de. Análise do marco civil da internet. Jus Navigandi, Teresina, ano 17, n.3208, 13/abr/2012. Disponível em: <http://jus.com.br/revista/texto/21474. Acesso em: 23 abr. 2012 
Artigo original

Hegemonia - Revista Eletrônica de Relações Internacionais do Centro Universitário Unieuro

ISSN: $1809-1261$

UNIEURO, Brasília, número 10, 2012, pp. 158-252.

comunicação em rede. Alterando a chave de leitura que amparava o projeto de lei de cibercrimes, 0 Marco Civil estava preocupado primordialmente não com as investigações ou punições a crimes praticados pela Internet, mas, antes, dando um passo atrás, com a positivação de uma interpretação que permitisse ao Direito dialogar com a Internet sem desrespeitar a natureza desta e sem pretender efeitos inatingíveis por aquele. A idéia se sintetizava na necessidade de um diálogo adequado entre o Direito e a Internet. ${ }^{30}$

Entretanto, o projeto, apesar de sua iniciativa democrática, sofre críticas conforme comentado por Aisla Araújo:

Apesar de o Projeto de Lei 2126/2011 ter sido elaborado de modo colaborativo, ou seja, com a participação da sociedade, surgiram muitos comentários contrários à iniciativa de regular a Internet, com a alegação de que o Marco Civil da Internet tolheria a liberdade de expressão e segurança de dados pessoais. Entretanto, coube aos defensores do Marco Civil da Internet a justificativa de que os artigos PL 2126/2011 visam evitar que a Internet seja utilizada como meio para prática de delitos, proporcionando mais segurança no ciberespaço ao mesmo tempo em que não fere direitos fundamentais previstos na Constituição Federal - CF. ${ }^{31}$

30

SANTARÉM, Paulo Rená da Silva. O direito achado na rede: a emergência do acesso à Internet como direito fundamental no Brasil. Brasília: UnB, 2010. p.102. Dissertação (Mestrado em direito, Estado e Constituição) Disponível em: <http://hdl.handle.net/10482/8828> Acesso em: 01 mai 2012 
Artigo original

Hegemonia - Revista Eletrônica de Relações Internacionais do Centro Universitário Unieuro

ISSN: $1809-1261$

UNIEURO, Brasília, número 10, 2012, pp. 158-252.

A advogada, especialista em direito digital, Patrícia Peck em entrevista a TN considera sobre o atraso do Brasil em relação a outras nações quando o assunto é regulamentação da Internet. A questão já era discutida na Europa na década de oitenta, quando foi definida a tutela da matéria envolvendo a liberdade informática, conforme segue:

A Convenção do Conselho da Europa, de 28-1-1981, fixa princípios de proteção para as pessoas com referência a elaboração automática de dados de caráter pessoal e reconhece tutela jurídica ao novo direito de liberdade de informática.

A liberdade informática é o direito de dispor da informação, de preservar a própria identidade informática, isto é, de consentir, controlar, retificar os dados informativos relativos à própria personalidade. Ao direito de informar e ser informado uniu-se o direito de tutelar a "liberdade de informação" como bem pessoal e interesse civil. 32

Esse atraso torna-se evidente ao pesquisar o assunto em outros ordenamentos jurídicos e como a legislação alienígena vem sendo aplicada às questões do direito cibernético. Por este motivo, alguns estudiosos do direito de Internet questionam a eficácia do projeto de lei proposto, visto que não há até o momento base legal para resolver os litígios provenientes da rede mundial. Segundo os especialistas, não internacional do software. São Paulo: Atlas, 2007. p.20 
Artigo original

Hegemonia - Revista Eletrônica de Relações Internacionais do Centro Universitário Unieuro

ISSN: $1809-1261$

UNIEURO, Brasília, número 10, 2012, pp. 158-252.

só da área do direito mas também da área de informática, da forma como está o texto o projeto pode ser um retrocesso em relação a responsabilidade, já definida no Código civil, do Consumidor e na Constituição Federal. De certa forma favorece o anonimato, o que é expressamente proibido pela Constituição Federal.

Muitos países da América Latina já tratam desde 2002 sobre proteção de dados sensíveis, em termos Globais a Europa já atualizou muitas questões dos novos tipos de crimes eletrônicos. Estamos discutindo projetos de lei há mais de 10 anos sem termos conseguido melhorar a atualização das mesmas no cenário mais digital. Além disso, a título de exemplo, os Estados Unidos possuem uma lei federal contra invasão de sistemas bancários e do governo, além de cada estado possuir sua lei específica para invasão de privacidade, acesso indevido de dados ou invasão de sistemas não coberto pela lei federal acima, também, esse país já proibiu atividades como o SPAM em nível federal. $O$ Canadá também possui legislação contra o SPAM, mas nada ainda similar ao Marco Civil da Internet. Na Europa, França, Inglaterra e Irlanda já tomaram medidas severas de controle contra o compartilhamento indevido de conteúdo, impondo castigos de interrupção de prestação de serviços de acesso à internet, no entanto, não há consenso dos demais países em impor tal medida (Alemanha, por exemplo). China, Turquia e países fundamentalistas religiosos ou totalitários não possuem a internet livre. Dentre os países da América Latina podemos destacar a Argentina, Venezuela, Chile, Paraguai e Uruguai como já possuindo legislação específica aos crimes denominados de digitais (informáticos ou cibernéticos), que compreendem, dentre outros, 0 acesso não autorizado a sistemas (invasão), envio 
Artigo original

Hegemonia - Revista Eletrônica de Relações Internacionais do Centro Universitário Unieuro

ISSN: $1809-1261$

UNIEURO, Brasília, número 10, 2012, pp. 158-252.

de códigos maliciosos e apropriação indevida de dados. ${ }^{33}$

Fato que preocupa, é a morosidade do legislativo no processo legislativo. Há mais de dois anos o projeto de lei vem sendo discutido e até o presente momento, apesar de estar tramitando em regime de urgência, não há previsão para que seja votado. Para complicar ainda mais o processo, foi apensado ao projeto de lei 5.403/2001, de autoria do Senador Luiz Estevão. Cabe comentar que, atualmente, existem quarenta projetos de lei apensados ao de número $5.403 / 2001$, todos versando sobre direito digital, o que demonstra a preocupação dos parlamentares em fazer propostas de regulamentação para a matéria. Entretanto, o legislativo permanece inerte.

O tema é polêmico e causa divergências entre os especialistas, muitos acreditam ser o projeto de lei um retrocesso, outros já entendem ser um grande avanço apenas por estar realmente sendo a matéria tratada pelo legislativo, visto os inúmeros projetos que nunca saíram do âmbito de analise. O fato é que depois de tantas tentativas em regular o direito virtual o projeto traz nova luz sobre a matéria, mesmo que ainda eivado de inconstitucionalidades ou lacunas, como vários especialistas consideram.

Em matéria publicada no site da American Chamber of Commerce (Amcham), advogados especialistas da área fazem

\section{3}

PECK, Patrícia. Especialista em direito digital comenta o Marco Civil da Internet no Brasil. Disponível em: <http://www.portaltelenoticias.com/2011/10/telenoticias-entrevista-patriciapeck.html> Acesso em 30 abr 2012 
Artigo original

Hegemonia - Revista Eletrônica de Relações Internacionais do Centro Universitário Unieuro

ISSN: $1809-1261$

UNIEURO, Brasília, número 10, 2012, pp. 158-252.

considerações sobre o retrocesso que a lei irá gerar caso aprovada da forma como o texto se encontra, in verbis:

"O Marco Civil da internet, de acordo com seu texto atual, em boa parte representa um retrocesso na nossa legislação, salvo a política de educação digital", disse Renato Opice Blum, sócio do escritório Opice Blum Advogados, coordenador do curso de Direito Digital da Fundação Getúlio Vargas/GV Law e presidente do comitê da Amcham.

"O projeto não traz grandes inovações. Há alguns pontos positivos de princípios estabelecidos, mas, de certo modo, na prática, há apenas algumas mudanças pontuais", afirmou Leandro Bissoli, sócio do escritório Patrícia Peck Pinheiro Advogados e especialista em Direito Digital. Nessa linha, Opice Blum concordou que, além de o projeto repetir aspectos da legislação, aborda fatos já pacificados na jurisprudência.

Bissoli avaliou inclusive que o marco regulatório não agregará maior segurança aos usuários no ambiente da web. "Em se tratando de segurança, o arcabouço legal existente já trata disso."34

Deve-se considerar ainda que durante as discussões, não houve a pretensão em abranger todos os temas relacionados com o direito virtual, pois matérias como direito autoral, comércio eletrônico, certificação digital dentre outros já haviam sido objeto de projetos de

\section{4}

ROCHA, Daniela. Projeto do Marco Civil da Internet não inova e apresenta alguns retrocessos, dizem especialistas. Disponível em: <http://www.amcham.com.br/regionais/amcham-sao-paulo/noticias/2011/projeto-do-marco-civilda-internet-nao-inova-e-apresenta-alguns-retrocessos-dizem-especialistas> Acesso em: 02 mai 2012 
Artigo original

Hegemonia - Revista Eletrônica de Relações Internacionais do Centro Universitário Unieuro

ISSN: $1809-1261$

UNIEURO, Brasília, número 10, 2012, pp. 158-252.

lei que ainda tramitam no Congresso. Com isso, evitou-se tratar novamente dessas matérias focalizando apenas o uso da Internet, conforme esclarece Paulo Santarém, in verbis:

O foco do Marco Civil era unicamente o uso da Internet. Todas as discussões sobre temas como o direito ao acesso, à liberdade de expressão e à privacidade, à não discriminação de conteúdos e a resolução de conflitos relacionados à rede, entre outros, teriam como fim estabelecer parâmetros legais relativos ao universo das diversas formas de uso da rede. Tudo articulado nos três eixos centrais: direitos, deveres e atribuições do poder público. ${ }^{35}$

O Marco Civil da Internet é mais uma tentativa de regular as atividades virtuais, entretanto este projeto de lei conta com um ponto a mais, a pressão popular, que exige do legislativo um posicionamento concreto sobre a matéria, visto o ambiente de insegurança jurídica existente hoje em relação a situações jurídicas provenientes da rede. Patrícia Peck, considera que não basta haver um documento legal para que esse seja eficaz, é necessário que este documento responsabilize os atores envolvidos nas relações jurídicas, in verbis:

Para haver eficácia jurídica e coibição da prática de crimes como falsa identidade, distribuição de conteúdo não autorizado, pirataria, plágio etc, qualquer medida legal necessita envolver os provedores de acesso e provedores de páginas que 
Artigo original

Hegemonia - Revista Eletrônica de Relações Internacionais do Centro Universitário Unieuro

ISSN: $1809-1261$

UNIEURO, Brasília, número 10, 2012, pp. 158-252.

permitem publicação de conteúdo por terceiros e empresas de hospedagem de sites. Caso contrário, uma lei ou uma ordem judicial não conseguirão atingir a eficácia plena nas medidas destinadas a reestabelecer a ordem jurídica no combate aos crimes na internet ${ }^{36}$

Ocorre que nesse ponto, o projeto de lei 2126/2011 é omisso em vários pontos, o que possivelmente irá comprometer a eficácia do documento legal. Devido a essas lacunas, dependendo do caso concreto, a lei não gerará a tão almejada segurança jurídica.

Cabe salientar que o projeto em questão conta apenas com cinco capítulos e a pretensão de regulamentar o mundo virtual. Estranho imaginar que tão poucos artigos possam surtir real eficácia em um campo que está em constante mutação e evolução, um mundo onde pessoas de culturas e hábitos diferentes estão em continua troca de informações.

O surgimento da rede mundial de computadores permitiu que a troca de informações acontecesse com maior celeridade e de forma global, mantendo um grande número de pessoas conectadas em um mundo onde a diversidade e a possibilidade de escolha são infinitas. ${ }^{37}$

\section{6}

PECK, Patrícia Disponível em: <http://www.leieordem.com.br/censura-vint-cerf-pai-dainternet-de-tao-danoso-sopa-precisa-ser-revisto.html> Acesso em 30 abr.2012

LEAL, Sheila do Rocio Cercal Santos. Contratos eletrônicos: validade jurídica dos Contratos via Internet. São Paulo: Atlas, 2007. p.8 
Artigo original

Hegemonia - Revista Eletrônica de Relações Internacionais do Centro Universitário Unieuro

ISSN: $1809-1261$

UNIEURO, Brasília, número 10, 2012, pp. 158-252.

Sendo a Internet um mundo de possibilidades infinitas, conforme o entendimento de Sheila Leal, como acreditar que apenas cinco capítulos poderão realmente cumprir seu papel? É possível que apenas este documento legal traga efetivamente segurança jurídica, para dentro do ordenamento brasileiro, no que tange o direito virtual?

Apesar de o legislador não ter intencionado abranger todos os aspectos jurídicos da internet, deveria ter sido elaborado um documento mais genérico, então. Uma norma que fosse geral e pudesse ser utilizada de forma interpretativa, como é o caso da Constituição Norte America, que possui poucos artigos, mas que devido seu caráter genérico, tutela de forma eficaz os direitos naquela Nação.

Passemos a análise do projeto de lei 2126/2011.

O Marco Civil da Internet é apresentado em cinco capítulos. O primeiro trata dos fundamentos, dos conceitos para interpretação do documento e dos objetivos que o norteiam. O segundo capítulo enumera os direitos dos usuários, afirma que o acesso à Internet está relacionado ao exercício da cidadania, assim como também a Organização das Nações Unidas (ONU) defende, e discorre sobre garantias como a de não ter o acesso à Internet interrompido. Assuntos polêmicos como responsabilidades por danos decorrentes de ações na Internet, solicitação de histórico de registros, privacidade, tráfego de dados, dentre outros são tratados no terceiro capítulo. A atuação do poder público quanto à Internet está definida no quarto capítulo que discorre sobre regras para sites públicos, atuação no desenvolvimento da Internet no Brasil, incentivo cultural e padronização quanto à 
Artigo original

Hegemonia - Revista Eletrônica de Relações Internacionais do Centro Universitário Unieuro

ISSN: $1809-1261$

UNIEURO, Brasília, número 10, 2012, pp. 158-252.

utilização de tecnologias. O quinto e último capítulo finaliza garantindo o exercício dos direitos de uso da Internet de modo individual e coletivo. ${ }^{38}$

\subsection{DISPOSIÇÕES PRELIMINARES}

O capítulo I, que trata das disposições preliminares, é composto dos artigos $1^{0}$ ao 60 , traz em seu bojo fundamentos, princípios, objetivos, além de definir o significado de terminologia específica da área de informática em relação ao documento legal e o direito de Internet.

O primeiro capítulo do Projeto de Lei expõe os fundamentos, princípios e objetivos estabelecidos quanto à regulação do uso da Internet no Brasil. É reconhecida a amplitude mundial da Internet $e$ apontado como um dos fundamentos da utilização do ciberespaço o "exercício da cidadania em meios digitais" e os Direitos Humanos. Quanto aos princípios que regem o Marco Civil da Internet, destaca-se a preocupação em garantir a proteção da privacidade e informações pessoais dos usuários, bem como a característica colaborativa da Internet. ${ }^{39}$

Os artigos $1^{0}$ a $3^{\circ}$ trazem a base da lei, ao listar os fundamentos, princípios e objetivos do documento legal. Cabe

ARAÚJO, Aisla Neilia de. Op. Cit. 
Artigo original

Hegemonia - Revista Eletrônica de Relações Internacionais do Centro Universitário Unieuro

ISSN: $1809-1261$

UNIEURO, Brasília, número 10, 2012, pp. 158-252.

ressaltar que o projeto possui como princípios a garantia da liberdade de expressão, comunicação e manifestação de pensamento, nos termos da Constituição, assim como oferece proteção à privacidade e aos dados pessoais. Ao analisarmos esta informação questiona-se qual a real intenção do legislador, visto que a Constituição em seu artigo 50 garante ser livre a expressão do pensamento, vedado o anonimato. Da mesma forma ocorre com a atividade intelectual, artística, cientifica. Garante ainda o mesmo artigo em seu inciso $X$, que são invioláveis a intimidade, a vida privada, a honra e a imagem das pessoas, assegurado o direito a indenização pelo dano material ou moral decorrente de sua violação.

Neste contexto, encontramos o calcanhar de Aquiles não só do projeto de lei, como veremos a seguir, mas do funcionamento e utilização da Internet.

Já os objetivos definidos no artigo 40 são genéricos e não inovam no que diz respeito a segurança e proteção do usuário.

Art. 4 A disciplina do uso da Internet no Brasil tem os seguintes objetivos:

I - promover o direito de acesso à Internet a todos os cidadãos;

II - promover o acesso à informação, ao conhecimento e à participação na vida cultural e na condução dos assuntos públicos;

III- promover a inovação e fomentar a ampla difusão de novas tecnologias e modelos de uso e acesso; e

IV - promover a adesão a padrões tecnológicos abertos que permitam a comunicação, a 
Artigo original

Hegemonia - Revista Eletrônica de Relações Internacionais do Centro Universitário Unieuro

ISSN: $1809-1261$

UNIEURO, Brasília, número 10, 2012, pp. 158-252.

acessibilidade e a interoperabilidade entre aplicações e bases de dados. ${ }^{40}$

O enfoque dado no artigo é voltado para a abertura e acesso da população às informações disponíveis na rede mundial e a obrigatoriedade da transparência em relação as ações governamentais. Por um outro enfoque, Aisla Araújo defende que o artigo em questão ter como objetivo a promoção do acesso à internet a todos os cidadãos é a uma inovação sem precedentes dentro do âmbito legislativo:

De acordo com o artigo 4 $\square$, o Marco Civil da Internet visa conduzir à utilização do ciberespaço para a propagação de conhecimento e cultura, além de ser meio de comunicação de assuntos públicos. Objetiva a promoção do "direito de acesso à Internet a todos os cidadãos" e o estimula a adesão de padrões tecnológicos abertos por parte de todos os níveis da federação. O grande diferencial deste Projeto de Lei para outros que tramitam pelo Legislativo é que, ao contrário de focar em questões criminais, o ponto de partida é estabelecer direitos e deveres com relação à utilização da Internet assegurando o exercício dos direitos constitucionais dos quais todos os cidadãos brasileiros dêem se valer. $^{41}$

\footnotetext{
40

BRASIL. Projeto de Lei 2126/2011: estabelece princípios, garantias, direitos e deveres para uso da Internet no Brasil. Disponível em: <http://www.camara.gov.br/proposicoesWeb/fichadetramitacao?id Proposicao $=517255>$
} 
Artigo original

Hegemonia - Revista Eletrônica de Relações Internacionais do Centro Universitário Unieuro

ISSN: $1809-1261$

UNIEURO, Brasília, número 10, 2012, pp. 158-252.

Interessante também é a análise do artigo $6^{\circ}$ que dispõe as fontes a serem utilizadas na interpretação da Lei:

Art. 6. Na interpretação desta Lei, serão levados em conta, além dos fundamentos, princípios e objetivos previstos, a natureza da Internet, seus usos e costumes particulares e sua importância para a promoção do desenvolvimento humano, econômico, social e cultural. ${ }^{42}$

De acordo com o artigo em questão, além dos fundamentos, princípios e objetivos previstos, serão levados em conta a natureza da Internet, seus usos e costumes particulares e sua importância para a promoção do desenvolvimento humano, econômico, social e cultural. Em um primeiro momento, o artigo parece ser muito amplo, tornando a aplicação da lei uma tarefa quase Hercúlea para o magistrado, que pode se apoiar em várias fontes para sua decisão e que enfim, continuará decidindo de acordo com seus conhecimentos e experiências, não fornecendo o documento a segurança jurídica pretendida.

\subsection{DOS DIREITOS E GARANTIAS DOS USUÁRIOS}

Discussão interessante é a do segundo capítulo, o qual versa sobre os direitos do usuário. De início o artigo 70 traz em seu bojo que

\footnotetext{
42

BRASIL. Projeto de Lei 2126/2011: estabelece princípios, garantias, direitos e deveres

para 0 uso da Internet no Brasil. Disponível em: <http://www.camara.gov.br/proposicoesWeb/fichadetramitacao?idProposicao=517255>
} 
Artigo original

Hegemonia - Revista Eletrônica de Relações Internacionais do Centro Universitário Unieuro

ISSN: $1809-1261$

UNIEURO, Brasília, número 10, 2012, pp. 158-252.

o acesso a Internet é essencial ao exercício da cidadania. O acesso a internet é uma facilidade para que o indivíduo se informe melhor e possa exercer seus direitos de forma adequada. Essencial para cidadania é o sujeito exercer os seus direitos de forma consciente, é votar e eleger os seus governantes, é ter direitos e deveres dentro do grupo social do qual faz parte.

O segundo capítulo não é extenso, sendo composto de apenas dois artigos, os quais garantem os direitos e garantias dos usuários, versando sobre inviolabilidade e sigilo das comunicações pela Internet e questões relativas aos contratos de conexões à Internet e a prestação do serviço. Traz ainda a garantia do direito à privacidade e a à liberdade de expressão para o pleno exercício do direito de acesso à Internet.

Cabe ressaltar que a liberdade de expressão garantida no artigo $8^{\circ}$ do projeto de lei, por força do artigo 50, IV, da Constituição Federal, é de certa forma limitada, pois, conforme já citado anteriormente, é livre a manifestação do pensamento sendo vedado o anonimato. Ora, se o direito a privacidade e a liberdade de expressão é condição para o pleno exercício do direito de acesso à Internet deparamos então com um conflito entre a lei e a Constituição, pois pelo teor do artigo $8^{\circ}$ essa liberdade de expressão é irrestrita, sem censura, e portanto não havendo que se falar em limitações.

Entretanto, se voltarmos ao artigo 30 , I, do projeto de lei encontramos que essa garantia deve estar de acordo com os termos da Constituição. Ou seja, a liberdade garantida, na verdade é uma liberdade vigiada onde o Estado poderá monitorar todos os atos 
Artigo original

Hegemonia - Revista Eletrônica de Relações Internacionais do Centro Universitário Unieuro

ISSN: $1809-1261$

UNIEURO, Brasília, número 10, 2012, pp. 158-252.

daquele cidadão. Ora, para qualquer pessoa que navegue pela Internet não é novidade as milhares de páginas, blogs e posts sem assinatura do responsável, ou mesmo com pseudônimos.

Muitas pessoas, por vezes querem se expressar, mas devido a seu cargo, ou mesmo por resguardar sua privacidade o fazem com codinomes, criam contas e perfis falsos. O que não é correto, mas é uma prática comum no ambiente virtual e, pela letra do artigo $6{ }^{\circ}$, do projeto de lei, quando diz que na interpretação da Lei serão considerados além dos fundamentos e princípios a natureza da Internet, seus usos e costumes particulares, seria então dessa forma permitido.

O que fica pouco claro é a real intenção do legislador. Pois, se deve ser respeitada a natureza da Internet, antes de mais nada, devese prezar pela liberdade irrestrita da expressão. Tal fato certamente colidiria com direitos fundamentais garantidos pela Constituição como inviolabilidade à intimidade, vida privada, honra e imagem.

Sendo assim, pelo exemplo dado, percebe-se que as garantias colidem entre si. Como manter a privacidade e ao mesmo tempo poder expressar os pensamentos conforme o que rege a Constituição? De acordo com Túlio Vianna, apud Marcel Leonardi, "o direito à privacidade deve ser concebido como uma tríade: a) direito de não ser monitorado; b) direito de não ser registrado; c) direito de não ser reconhecido"43. Ocorre que, ao garantir a liberdade de expressão, desde que não seja anônima, a lei estará, de certa forma, interferindo 
Artigo original

Hegemonia - Revista Eletrônica de Relações Internacionais do Centro Universitário Unieuro

ISSN: $1809-1261$

UNIEURO, Brasília, número 10, 2012, pp. 158-252.

na privacidade do cidadão, visto que é uma forma de controle ou monitoramento do Estado.

\subsection{DA PROVISÃO DE CONEXÃO E DE APLICAÇÕES DE INTERNET}

O capítulo terceiro da lei é sem dúvida alguma o mais discutido e questionado pelos operadores do direito, visto que trata da questão de processamento e armazenamento de dados. É composto por quatro seções e abrange do artigo $9^{\circ}$ ao $18^{\circ}$ da lei, considerando que 0 projeto de lei tem ao todo 25 artigos, percebe-se claramente que houve maior ênfase em tutelar a relação entre provedores e usuários do que os direitos e garantias destes em relação a rede.

A redação do artigo 90 traz em seu bojo que o responsável pela transmissão, comutação ou roteamento tem o dever de tratar de forma isonômica quaisquer pacotes de dados, sem distinção por conteúdo, origem e destino. Sendo vedada qualquer discriminação ou degradação do tráfego. Para tentarmos entender melhor o artigo cito a explanação sobre o assunto Aisla Araújo:

[...] muitas empresas, supostamente, fazem distinção quanto aos tipos de conteúdos que trafegam na Internet, isso justificaria situações de degradação de banda, relatadas por usuários de banda larga, ao tentarem estabelecer conexões usando protocolos de transferências, o que caracteriza maior consumo de banda para troca de grandes arquivos entre servidores.

A moderação de tráfego faz com que as empresas de telefonia e provedores de internet não precisem 
Artigo original

Hegemonia - Revista Eletrônica de Relações Internacionais do Centro Universitário Unieuro

ISSN: $1809-1261$

UNIEURO, Brasília, número 10, 2012, pp. 158-252.

injetar mais investimentos em infraestrutura para atender a grande demanda que surgiria caso fossem sustentar, de fato, a velocidade de conexão que anunciam ao venderem assinaturas de serviços de internet, visto que a grande maioria dos usuários consome pequena quantidade de banda em seu uso diário do ciberespaço. ${ }^{44}$

O artigo apesar de proteger o tratamento isonômico da informação comutada permite em seu parágrafo final, quando diz que é vedado a degradação do tráfego, possibilita às empresas, sob justificativa de limitação de infraestrutura, que prossigam com a prática da moderação de tráfego de informações, dessa forma ao invés de obrigá-las a investir no produto oferecido para atender a demanda de seus clientes, possibilita o cerceamento na comutação de pacotes.

Outro ponto interessante a ser discutido é a guarda dos registros e da responsabilidade dos provedores pelo conteúdo disponibilizado na rede por terceiros. A matéria é tratada nos artigos 10 a 18 do projeto de lei e foi alvo de várias críticas de advogados e especialistas.

Um dos pontos cruciais da discussão é relativo à guarda dos registros, pois o projeto de lei, apesar de prever a guarda dos dados de registros de conexão pelo prazo de um ano, veda a guarda de registros de acesso a aplicações de internet na provisão de conexão em seu artigo 12. Já no artigo 13 é facultado aos provedores guardarem os registros relativos ao acesso a aplicações, ou seja, páginas visitadas pelo internauta.

44

ARAUJO, Aisla Neila de. Op. Cit. 
Artigo original

Hegemonia - Revista Eletrônica de Relações Internacionais do Centro Universitário Unieuro

ISSN: $1809-1261$

UNIEURO, Brasília, número 10, 2012, pp. 158-252.

Embora exista a preocupação em proteger a privacidade dos usuários, a não obrigatoriedade de guarda dos registros de acesso a aplicações de Internet pode retardar investigações ou andamentos de processos que dependem de tais dados, uma vez que, assim como observou ELIA (2011), somente os dados de conexão podem não ser suficientes considerando a possibilidade de um usuário mal intencionado utilizar softwares que alteram seu real endereço de rede ou mesmo acessarem redes sem fio desprotegidas de modo a deixar rastros falsos pelo ciberespaço. ${ }^{45}$

Essa faculdade de armazenamento de informações é reforçada pelo Projeto de Lei ao isentar o provedor de danos decorrentes sobre o uso desses serviços por terceiros. De acordo com o previsto no Marco Civil, a responsabilidade só irá nascer para o provedor se, após demandado pelo judiciário, a tomar providências para retirar o conteúdo disponibilizado indevidamente por terceiro, este não o faça:

De acordo com os especialistas, o PL 2126/11 obriga os provedores a guardarem os registros de conexões dos usuários. Opice Blum afirma que, pela jurisprudência, essa medida já vinha sendo tomada pelas operadoras.

O grande retrocesso é que o projeto do marco regulatório torna facultativa a guarda dos registros dos provedores de aplicações como redes sociais, blogs e e-mails. "Isso poderá dificultar a rastreabilidade e identificação dos usuários",

45

Ibid. 
Artigo original

Hegemonia - Revista Eletrônica de Relações Internacionais do Centro Universitário Unieuro

ISSN: $1809-1261$

UNIEURO, Brasília, número 10, 2012, pp. 158-252.

ressaltou Leandro Bissoli. Nesse caso, se uma pessoa abrir uma conta falsa no Gmail ou um perfil falso no Facebook com a finalidade de praticar crimes, será muito complicado investigá-la ou localizá-la, exemplificou Opice Blum.

Outro problema identificado pelos advogados é que será mais demorado o processo para retirada de conteúdos indevidos na internet, como os relacionados a pedofilia, pornografia ou ofensas às pessoas. Assim, as vítimas serão mais prejudicadas, uma vez que, na rede, as informações se espalham com facilidade e rapidez.

Bissoli explicou que hoje, ao ser notificado extrajudicialmente, o provedor de aplicação pode retirar o conteúdo $e$, se não fizer isso, assume automaticamente a responsabilidade em relação à informação publicada. "O marco civil indica que somente por ordem judicial será possível retirar conteúdo da internet. Sem essa ordem, os provedores podem se recusar. O Judiciário pode ficar 'entupido' e a demora é ruim para as vítimas." 46

O que salta aos olhos é que esse tratamento dado a questão pode ser mais prejudicial do que benéfico. A vigilância sobre os dados comutados é entendida como inconstitucional, entretanto a guarda de um histórico dentro da Internet deveria ser obrigatório pelo menos por um período de três anos. Neste caso o prazo seria condizente com o artigo 206, §3, do Código Civil para prescrição da pretensão de

\section{6}

ROCHA, Daniela. Projeto do Marco Civil da Internet não inova e apresenta alguns retrocessos, dizem especialistas. Disponível em: <http://www.amcham.com.br/regionais/amcham-sao-paulo/noticias/2011/projeto-do-marco-civilda-internet-nao-inova-e-apresenta-alguns-retrocessos-dizem-especialistas> Acesso em: 02 mai 2012 
Artigo original

Hegemonia - Revista Eletrônica de Relações Internacionais do Centro Universitário Unieuro

ISSN: $1809-1261$

UNIEURO, Brasília, número 10, 2012, pp. 158-252.

reparação civil. Dessa forma, caso houvesse alguma infração, que suscitasse a reparação civil, seria fácil para os agentes responsáveis fizessem o monitoramento das atividades e obtivessem provas para instruir o processo. Obviamente estes dados teriam caráter sigiloso, somente podendo ser acessados nos casos em que a justiça demandasse, conforme previsto no projeto em análise. Sobre a questão do prazo Aisla Araujo considera:

[...] no tocante ao tempo de guarda dos registros de conexão. No artigo 11, o Projeto de Lei define que os registros sejam guardados pelo prazo de um ano, em um ambiente seguro e sigiloso. Embora alguns interessados no assunto defendam que a guarda dos registros devam obedecer a um limite mínimo de tempo de três anos, como o Senador Eduardo Azeredo no SEM 89/2003, o professor Ronaldo Lemos em entrevista ao site Arede (sic) argumenta que, em estudo feito pela União Européia, 98,0\% das solicitações de registros de acesso referem-se a dados guardados há até um ano, e apenas $2,0 \%$ das solicitações referem-se a dados que ultrapassam este prazo.

Contudo, ao considerar detalhes concernentes à realidade jurídica no Brasil e o fato de que a prescrição civil, em geral, ocorre em cinco anos é possível questionar a viabilidade da guarda de registros de conexão abranger, apenas, um ano. Ainda no artigo 11, no parágrafo segundo, é proposto que os registros de conexão podem ser guardados por tempo superior ao previsto no Projeto de Lei, contanto que exista requerimento de autoridade policial ou administrativa. Essas disposições podem, também, retardar ou dificultar investigações de crimes cometidos por meio da Internet há mais de um ano. Embora a prescrição 
Artigo original

Hegemonia - Revista Eletrônica de Relações Internacionais do Centro Universitário Unieuro

ISSN: $1809-1261$

UNIEURO, Brasília, número 10, 2012, pp. 158-252.

criminal varie de acordo com o ilícito praticado, a maioria ultrapassa o prazo de uma ano. ${ }^{47}$

Da forma como ficou a redação do capítulo, a sensação que se tem é que em casos de cibercrimes "a vítima digital não tem proteção nenhuma e o criminoso está mais protegido" 48 , utilizando-me aqui das palavras da Advogada Patrícia Peck. Se não há a responsabilidade do provedor pelos danos causados e nem a obrigatoriedade da guarda dos dados percebe-se que haverá certa dificuldade em comprovar o ato ilegal.

É importante perceber que o fato da não responsabilização do provedor, ao contrario censo, não é uma questão de fácil análise, visto que no entendimento de alguns doutrinadores essa responsabilidade deveria sim existir ainda que de forma subsidiária. Entretanto, explica Gustavo Correa, a própria Constituição Federal impede essa responsabilização conforme texto abaixo:

No Brasil inexiste lei imputando responsabilidade aos provedores de serviço por atos de seus usuários, nem mesmo no sentido de fiscalizar as suas ações; pelo contrário, a Constituição de 1988 até proíbe tal fiscalização, conforme o art. 50, XII, que diz: "(...) é inviolável o sigilo da correspondência e das comunicações telegráficas,

\section{7}

ARAÚJO, Aisla Neilia de. Op. Cit.

48

PECK,

Patrícia.

<http://convergenciadigital.uol.com.br/cgi/cgilua.exe/sys/start.htm?

Disponível

em: from_info_index=31\&infoid=26910\&sid=4> Acesso em 03 mai 2012 
Artigo original

Hegemonia - Revista Eletrônica de Relações Internacionais do Centro Universitário Unieuro

ISSN: $1809-1261$

UNIEURO, Brasília, número 10, 2012, pp. 158-252.

de dados e das comunicações telefônicas, salvo, no ultimo caso, por ordem judicial, nas hipóteses e na forma que a lei estabelecer para fins de investigação criminal ou instrução processual penal (...)".

Ou seja, além de inexistir lei acerca da responsabilidade dos provedores, existe norma constitucional que lhes proíbe o exame dos dados de seus servidores. Também, é impossível a fiscalização de todas as informações que entram e saem de um provedor, pois, além de servir seus usuários, também serve de "pista" para a Internet. Assim, um infindável número de informações, como e-mails, homepages, listas de discussões, chats, é atualizado instantaneamente por meio de procedimentos eletrônicos automáticos, sobre os quais o provedor não tem nenhum controle. Como responsabilizar alguém por aquilo a que não deu causa? ${ }^{49}$

Partindo do pressuposto que não é possível vincular o provedor com os delitos, ou por que não dizer o mau uso da Internet, é necessário encontrar uma forma de instruir o usuário em como utilizar o serviço sem que viole as regras de boa conduta que regem a sociedade. As normas para uma navegação adequada deveriam ser claras, como se fosse um curso de boas maneiras para o mundo virtual. Ocorre que na sociedade dos sem tempo, ninguém se preocupa em parar para ler o contrato de prestação de serviço, quem dirá uma cartilha de conduta.

Considerando que não é possível, por força da carta magna, 
Artigo original

Hegemonia - Revista Eletrônica de Relações Internacionais do Centro Universitário Unieuro

ISSN: $1809-1261$

UNIEURO, Brasília, número 10, 2012, pp. 158-252.

responsabilizar os provedores, ou promover qualquer tipo de controle de informações que trafegam pela Internet, o ideal seria que, de acordo com Gustavo Testa Correa,

Os provedores devem esclarecer e fixar, por via contratual, a responsabilidade de seus usuários acerca de condutas delituosas que venham a ferir o ordenamento jurídico brasileiro, tornando claro o seu posicionamento perante tais ações. Afinal, sendo impossível a tipificação de todas as condutas delituosas possíveis, ao mesmo tempo em que a tecnologia contribui para o desenvolvimento de uma ciência jurídica eficaz e válida, criando respostas rápidas para uma sociedade cada vez mais complexa. ${ }^{50}$

O questionamento que permanece é: qual a finalidade de se criar uma lei que não regula, orienta ou tutela os direitos fundamentais garantidos pela Constituição? O direito à inviolabilidade da privacidade, imagem e honra já são garantido na Carta Magna e portanto, apesar de reforçados no projeto de lei, não trazem inovação alguma para o cidadão.

\subsection{DA ATUAÇÃO DO PODER PÚBLICO}

Já o capítulo quatro trata da atuação do poder público frente ao 
Artigo original

Hegemonia - Revista Eletrônica de Relações Internacionais do Centro Universitário Unieuro

ISSN: $1809-1261$

UNIEURO, Brasília, número 10, 2012, pp. 158-252.

desenvolvimento da Internet, traçando diretrizes para que o Estado possa intervir e fomentar o desenvolvimento do ambiente virtual e da sociedade globalizada. É perceptível neste ponto do projeto de lei, a boa vontade do legislador em ofertar condições de conscientização e informação da população em relação a Internet e sua utilidade.

Vislumbra-se um avanço por parte do legislador ao incentivar a promoção da Internet e cultura digital como ferramenta social. Além de fomentar a inclusão social buscando diminuir as desigualdades principalmente entre as regiões do país. O que está em perfeita consonância com o artigo $3^{\circ}$ da Constituição Federal que lista como objetivos fundamentais da República Federativa do Brasil, a construção de uma sociedade livre; a garantia do desenvolvimento nacional e a redução das desigualdades sociais e regionais.

Assim, pretende o legislador que o Estado crie formas de difundir o ambiente da rede não só nas regiões produtivas da Federação, mas também nos municípios que possuem baixa renda per capta ou ainda aqueles locais isolados muito comuns no norte do país. O Estado, por força da Constituição tem como fundamento a cidadania e por este motivo deve propiciar o acesso igualitário a todo cidadão, já que, conforme disciplina o Marco Civil, a Internet é um meio para o exercício da cidadania garantida pela carta magna.

O inciso I do artigo 19 vai além ao estabelecer que os mecanismos de prestação de contas do governo devem ser transparentes e disponíveis ao cidadão, visando dessa forma uma gestão mais democrática e participativa da sociedade.

Destaque também deve ser dado ao artigo 21 o qual prevê que o 
Artigo original

Hegemonia - Revista Eletrônica de Relações Internacionais do Centro Universitário Unieuro

ISSN: $1809-1261$

UNIEURO, Brasília, número 10, 2012, pp. 158-252.

Estado deverá cumprir seu dever constitucional de tutela da sociedade na prestação, em todos os níveis de ensino, a capacitação dos usuários para o uso consciente e responsável da Internet. O que nos leva a crer que o Estado chama para si a responsabilidade por equipar as escolas públicas e prover o acesso dos estudantes, independente do nível escolar em que se encontrem, utilizando a Internet como ferramenta pedagógica de educação, integração e ensino.

Finalizando o capítulo reforça a responsabilidade do Estado em criar políticas, metas, e formas de fomentar o desenvolvimento da Internet no país.

Enfim, o projeto tem o escopo de estabelecer os princípios, garantias, direitos e deveres para o uso da Internet no âmbito brasileiro, entretanto, após a leitura de todos os artigos, parágrafos e incisos, não foi possível vislumbrar de forma clara a real intenção do legislador, visto que foram poucas garantias ofertadas, algumas até mitigavam as já existentes, como o caso da guarda das informações. Em relação aos direitos, muito pouco se tratou em relação a matéria, visto que aprovado como está o projeto carecerá de regulamentação que o complemente para que possa surtir algum efeito real no mundo jurídico. Outra questão que ficou bem obscura foi em relação aos deveres, pouco foi dito e quase nada esclarecido.

\section{CONCLUSÃO}

Após a análise do projeto de lei $2126 / 2011$, pode-se constatar que a respeito da observação às normas constitucionais não há nada 
Artigo original

Hegemonia - Revista Eletrônica de Relações Internacionais do Centro Universitário Unieuro

ISSN: $1809-1261$

UNIEURO, Brasília, número 10, 2012, pp. 158-252.

que desabone o corpo da lei. Os princípios de garantia a liberdade de expressão, comunicação e manifestação do pensamento são reforçados, assim como a proteção à privacidade.

Entretanto, apesar do projeto de lei ter tais princípios como alicerce, parece-me que a forma como foi disposto no corpo do texto, um tanto redundante, pois tais direitos já são Constitucionalmente garantidos. O interessante seria que o projeto de lei tratasse dos pontos onde estes princípios são conflitantes. O texto garante o direito à privacidade, mas não oferece as diretrizes para que essa tutela seja eficaz, visto que vez ou outra este direito pode conflitar com a liberdade de expressão. Conflito este já conhecido pelos doutrinadores do direito constitucional. Exemplo prático dessa situação no âmbito virtual seria a exposição de imagem não autorizada. Mais uma vez a resolução do conflito seria de acordo com a interpretação do magistrado que estaria julgando o caso concreto, sem que a lei oferecesse nenhum respaldo à solução deste conflito.

O projeto traz em seu bojo a pretensão em estabelecer princípios, garantias, direitos e deveres para o uso da Internet no Brasil. Entretanto, o texto nos termos como está redigido hoje tem sua eficácia notoriamente comprometida, pois faltam elementos para uma tutela efetiva dos conflitos provenientes do âmbito virtual.

Há a pretensão em estabelecer direitos e garantias, entretanto estes são elencados de forma pouco clara e muito genérica. Falta-Ihe o direcionamento de forma clara para que o usuário possa entender quais são seus reais direitos e principalmente o que ele deve fazer para resguardá-los. 
Artigo original

Hegemonia - Revista Eletrônica de Relações Internacionais do Centro Universitário Unieuro

ISSN: $1809-1261$

UNIEURO, Brasília, número 10, 2012, pp. 158-252.

Outro ponto obscuro no projeto é que ele define de forma ampla os direitos mas em momento algum menciona quais são os deveres do usuário. Tal fato, causa estranheza visto que o ordenamento jurídico é alicerçado nos direitos-deveres onde para que exista um direito em contrapartida haverá um dever por parte do cidadão. Visto dessa forma os direitos e deveres são institutos que caminham de mãos dadas, mas que foram separados no Marco Civil. Esquecimento do legislador? Talvez, mas esta é uma lacuna de extrema importância para que o projeto de lei realmente fosse eficaz, pois da forma como está garante-se apenas direitos mas não conscientiza o usuário de quais são os seus deveres. Sendo assim, já que não há limitações tudo será permitido.

Entendo que, apesar da boa vontade em se criar um documento legal para resguardar o direito virtual, não houve um estudo aprofundado de quais aspectos esta norma deveria abranger. Considerando a forma como foi criado o documento, parece-me que este acabou se tornando uma colcha de retalhos, com várias lacunas a serem supridas pelos demais projetos de lei que se encontram tramitando no Congresso Nacional, assim como pela legislação em vigor no país.

Dessa forma, fica claro que o Marco Civil por si só não atingirá seu objetivo, de forma eficaz, necessitando para isso de outros documentos legais que o complementem.

Pelo contexto do projeto de lei, os pontos cruciais das relações virtuais permanecem sem solução. Mesmo que o projeto de lei $2126 / 2011$ venha a ser aprovado e convertido em lei, da forma como 
Artigo original

Hegemonia - Revista Eletrônica de Relações Internacionais do Centro Universitário Unieuro

ISSN: $1809-1261$

UNIEURO, Brasília, número 10, 2012, pp. 158-252.

está hoje, o texto em nada modificará a forma como o judiciário vem trabalhando as questões do direito virtual. As decisões continuarão sendo pautadas na jurisprudência, analogia e demais documentos legais como o código civil, penal e do consumidor para julgar os casos em concreto. O que de certa forma não traz nenhuma novidade e muito menos segurança para o ordenamento jurídico.

Analisando por um prisma bem pessimista a conversão do projeto em lei traria sim um retrocesso ao que já está consolidado no ordenamento jurídico, pois como mencionado no corpo da pesquisa, não há nenhuma inovação consistente. Da forma como está o documento, faculta-se aos provedores a guarda das informações comutadas por seus usuários. O que de certa forma coloca os provedores em uma posição confortável perante os usuários e o judiciário, no que diz respeito a responsabilidade e obrigações.

Por fim, o que salta aos olhos é que apesar de o Marco Civil ser constitucional, deveria ser melhorado em vários aspectos para que realmente consiga ter eficácia jurídica no que diz respeito à tutela do direito virtual.

\section{REFERÊNCIA BIBLIOGRÁFICA}

ARAÚjO, Aisla Neilia de. Análise do marco civil da internet. Jus Navigandi, Teresina, ano 17, n.3208, 13/abr/2012. Disponível em: <http://jus.com.br/revista/texto/21474. Acesso em: 23 abr. 2012.

BARBOSA, Simone Diniz Junqueira. Interação humano-computador. Rio de Janeiro: Elsevier, 2010. p.1-15. 
Artigo original

Hegemonia - Revista Eletrônica de Relações Internacionais do Centro Universitário Unieuro

ISSN: $1809-1261$

UNIEURO, Brasília, número 10, 2012, pp. 158-252.

BARGALO, Erica Brandini. Contratos eletrônicos: contratos formados por meio de redes de computadores: peculiaridades jurídicas na formação do vinculo. São Paulo: Saraiva, 2001.

BOGO, Kellen Cristina. A história da internet - como tudo começou, $2000 . \quad$ Disponível em: <http://kplus.cosmo.com.br/materia.asp?co $=11 \&$ rv=Vivencia $>$ Acesso em: 14 de março de 2012.

BRASIL. Projeto de Lei 2126/2011: estabelece princípios, garantias, direitos e deveres para o uso da Internet no Brasil. Disponível em: <http://www.camara.gov.br/proposicoesWeb/fichadetramitacao?idProp osicao $=517255>$

CASTELLS, Manuel. A sociedade em rede São Paulo: Paz e Terra, 2005. p. 39-118.

CORREA, Gustavo Testa. Aspectos jurídicos da Internet. São Paulo: Saraiva, 2010. 169 p.

Dicionário Michaelis - online - verbete: princípio

Histórico da RNP. Disponível em: <http://www.rnp.br/rnp/historico.html> Acesso em: 19/04/12.

KUROSE, James. F. Redes de computadores e a internet. São Paulo: Pearson, 2010. p.1-60.

LAUDON, Kenneth C. Sistemas de informação gerenciais. São Paulo: Pearson, 2010. p. 164-185.

LEAL, Sheila do Rocio Cercal Santos. Contratos eletrônicos: validade jurídica dos Contratos via Internet. São Paulo: Atlas, 2007. 225 p.

LEONARDI, Marcel. Tutela e privacidade na Internet. São Paulo: Saraiva, 2012. p.11-182.

MEZRICH, Bem. Bilionários por acaso: a criação do Facebook. Rio de Janeiro: Intrínseca, 2010. p.228. 
Artigo original

Hegemonia - Revista Eletrônica de Relações Internacionais do Centro Universitário Unieuro

ISSN: $1809-1261$

UNIEURO, Brasília, número 10, 2012, pp. 158-252.

NUNES, Rizzatto. Manual de introdução ao estudo do direito. São Paulo: Saraiva, 2008. p.181-248.

OLIVEIRA, Régis Fernandes de. Liberdade de expressão e Internet. Revista de Direito das Comunicações, São Paulo, vol. 4, Jul. 2011. p.27-34.

PAESANI, Liliana Minardi. Direito de informática: comercialização e desenvolvimento internacional do software. São Paulo: Atlas, 2007. p.1-20.

PAINEL IBOPE NET/RATINGS. Disponível em: < http://www.cetic.br/usuarios/ibope/tab02-01-cons.htm> Acesso em: 19/04/12.

ZANIOLO, Pedro Augusto. Crimes modernos: o impacto da tecnologia no Direito. Curitiba: Juruá, 2007. 487 p.

PECK, Patrícia Disponível em: < http://www.leieordem.com.br/censuravint-cerf-pai-da-internet-de-tao-danoso-sopa-precisa-serrevisto.html> Acesso em 30 abr.2012.

PECK, Patrícia. Disponível em: <http://convergenciadigital.uol.com.br/cgi/cgilua.exe/sys/ start.htm?from_info_index=31\&infoid=26910\&sid=4> Acesso em 03 mai 2012.

PECK, Patrícia. Especialista em direito digital comenta o Marco Civil da Internet no Brasil. Disponível em: <http://www.portaltelenoticias.com/2011/10/telenoticias-entrevistapatricia-peck.html> Acesso em 30 abr 2012.

ROCHA, Daniela. Projeto do Marco Civil da Internet não inova e apresenta alguns retrocessos, dizem especialistas. Disponível em: $<$ http://www.amcham.com.br/ regionais/amcham-sao-paulo/noticias/2011/projeto-do-marco-civil-dainternet-nao-inova-e-apresenta-alguns-retrocessos-dizemespecialistas> Acesso em: 02 mai 2012. 
Artigo original

Hegemonia - Revista Eletrônica de Relações Internacionais do Centro Universitário Unieuro

ISSN: $1809-1261$

UNIEURO, Brasília, número 10, 2012, pp. 158-252.

SANTARÉM, Paulo Rená da Silva. O direito achado na rede: a emergência do acesso à Internet como direito fundamental no Brasil. Brasília: UnB, 2010. p.102. Dissertação (Mestrado em direito, Estado e Constituição) Disponível em: <http://hdl.handle.net/10482/8828> Acesso em: 01 mai 2012.

SANTOLIM, César Viterbo Matos. Formação e eficácia probatória dos contratos por computador. São Paulo: Saraiva, 1995.

SOUZA, Carlos Affonso Pereira de; MACIEL, Marília; FRANCISCO, Pedro Augusto. Marco Civil da Internet: uma questão de princípio. Revista poliTICs, n.7, Ago. 2010, Disponível em: <http://www.politics.org.br/sites/default/files/poliTICS_n07_souza_m aciel

_francisco.pdf> Acesso em: 23 abril 2012. 
Artigo original

Hegemonia - Revista Eletrônica de Relações Internacionais do Centro Universitário Unieuro

ISSN: $1809-1261$

UNIEURO, Brasília, número 10, 2012, pp. 158-252.

ANEXO A - PROJETO DE LEI 2126/2011

PROJETO DE LEI

Estabelece princípios, garantias, direitos e deveres para o uso da Internet no Brasil.

O CONGRESSO NACIONAL decreta:

\section{CAPÍTULO I DISPOSIÇÕES PRELIMINARES}

Art. $1^{\circ}$ Esta Lei estabelece princípios, garantias, direitos e deveres para o uso da Internet no Brasil e determina as diretrizes para atuação da União, dos Estados, do Distrito Federal e dos Municípios em relação à matéria.

Art. $2^{\circ}$ A disciplina do uso da Internet no Brasil tem como fundamentos:

I - o reconhecimento da escala mundial da rede;

II - os direitos humanos e o exercício da cidadania em meios digitais;

III - a pluralidade e a diversidade;

IV - a abertura e a colaboração; e

V - a livre iniciativa, a livre concorrência e a defesa do consumidor. 
Artigo original

Hegemonia - Revista Eletrônica de Relações Internacionais do Centro Universitário Unieuro

ISSN: $1809-1261$

UNIEURO, Brasília, número 10, 2012, pp. 158-252.

Art. $3^{\circ} \mathrm{A}$ disciplina do uso da Internet no Brasil tem os seguintes princípios:

I - garantia da liberdade de expressão, comunicação e manifestação de pensamento, nos termos da Constituição;

II - proteção da privacidade;

III - proteção aos dados pessoais, na forma da lei;

IV - preservação e garantia da neutralidade da rede, conforme regulamentação;

V - preservação da estabilidade, segurança e funcionalidade da rede, por meio de medidas técnicas compatíveis com os padrões internacionais e pelo estímulo ao uso de boas práticas;

VI - responsabilização dos agentes de acordo com suas atividades, nos termos da lei; e

VII - preservação da natureza participativa da rede.

Parágrafo único. Os princípios expressos nesta Lei não excluem outros previstos no ordenamento jurídico pátrio relacionados à matéria, ou nos tratados internacionais em que a República Federativa do Brasil seja parte.

Art. $4^{\circ} \mathrm{A}$ disciplina do uso da Internet no Brasil tem os seguintes objetivos:

I - promover o direito de acesso à Internet a todos os cidadãos;

II - promover o acesso à informação, ao conhecimento e à participação na vida cultural e na condução dos assuntos públicos;

III- promover a inovação e fomentar a ampla difusão de novas tecnologias e modelos de uso e acesso; e 
Artigo original

Hegemonia - Revista Eletrônica de Relações Internacionais do Centro Universitário Unieuro

ISSN: $1809-1261$

UNIEURO, Brasília, número 10, 2012, pp. 158-252.

IV - promover a adesão a padrões tecnológicos abertos que permitam a comunicação, a acessibilidade e a interoperabilidade entre aplicações e bases de dados.

Art. $5^{\circ}$ Para os efeitos desta Lei, considera-se:

I - Internet - o sistema constituído de conjunto de protocolos lógicos, estruturado em escala mundial para uso público e irrestrito, com a finalidade de possibilitar a comunicação de dados entre terminais por meio de diferentes redes;

II - terminal - computador ou qualquer dispositivo que se conecte à Internet;

III - administrador de sistema autônomo - pessoa física ou jurídica que administra blocos de endereço Internet Protocol - IP específicos e o respectivo sistema autônomo de roteamento, devidamente cadastrada no ente nacional responsável pelo registro e distribuição de endereços IP geograficamente referentes ao País;

IV - endereço IP - código atribuído a um terminal de uma rede para permitir sua identificação, definido segundo parâmetros internacionais; V - conexão à Internet - habilitação de um terminal para envio e recebimento de pacotes de dados pela Internet, mediante a atribuição ou autenticação de um endereço IP;

VI - registro de conexão - conjunto de informações referentes à data e hora de início e término de uma conexão à Internet, sua duração e o endereço IP utilizado pelo terminal para o envio e recebimento de pacotes de dados; 
Artigo original

Hegemonia - Revista Eletrônica de Relações Internacionais do Centro Universitário Unieuro

ISSN: $1809-1261$

UNIEURO, Brasília, número 10, 2012, pp. 158-252.

VII - aplicações de Internet - conjunto de funcionalidades que podem ser acessadas por meio de um terminal conectado à Internet; e VIII - registros de acesso a aplicações de Internet - conjunto de informações referentes à data e hora de uso de uma determinada aplicação de Internet a partir de um determinado endereço IP.

Art. $6^{\circ} \mathrm{Na}$ interpretação desta Lei, serão levados em conta, além dos fundamentos, princípios e objetivos previstos, a natureza da Internet, seus usos e costumes particulares e sua importância para a promoção do desenvolvimento humano, econômico, social e cultural.

\section{CAPÍTULO II \\ DOS DIREITOS E GARANTIAS DOS USUÁRIOS}

Art. $7^{\circ} \mathrm{O}$ acesso à Internet é essencial ao exercício da cidadania e ao usuário são assegurados os seguintes direitos:

I - à inviolabilidade e ao sigilo de suas comunicações pela Internet, salvo por ordem judicial, nas hipóteses e na forma que a lei estabelecer para fins de investigação criminal ou instrução processual penal;

II - à não suspensão da conexão à Internet, salvo por débito diretamente decorrente de sua utilização;

III - à manutenção da qualidade contratada da conexão à Internet, observado o disposto no art. $9^{\circ}$;

IV - a informações claras e completas constantes dos contratos de prestação de serviços, com previsão expressa sobre o regime de 
Artigo original

Hegemonia - Revista Eletrônica de Relações Internacionais do Centro Universitário Unieuro

ISSN: $1809-1261$

UNIEURO, Brasília, número 10, 2012, pp. 158-252.

proteção aos seus dados pessoais, aos registros de conexão e aos registros de acesso a aplicações de Internet, bem como sobre práticas de gerenciamento da rede que possam afetar a qualidade dos serviços oferecidos; e

V - ao não fornecimento a terceiros de seus registros de conexão e de acesso a aplicações de Internet, salvo mediante consentimento ou nas hipóteses previstas em lei.

Art. $8^{\circ} \mathrm{A}$ garantia do direito à privacidade e à liberdade de expressão nas comunicações é condição para o pleno exercício do direito de acesso à Internet.

\section{CAPÍTULO III \\ DA PROVISÃO DE CONEXÃO E DE APLICAÇÕES DE INTERNET Seção I \\ Do Tráfego de Dados}

Art. $9^{\circ}$ O responsável pela transmissão, comutação ou roteamento tem o dever de tratar de forma isonômica quaisquer pacotes de dados, sem distinção por conteúdo, origem e destino, serviço, terminal ou aplicativo, sendo vedada qualquer discriminação ou degradação do tráfego que não decorra de requisitos técnicos necessários à prestação adequada dos serviços, conforme regulamentação. 
Artigo original

Hegemonia - Revista Eletrônica de Relações Internacionais do Centro Universitário Unieuro

ISSN: $1809-1261$

UNIEURO, Brasília, número 10, 2012, pp. 158-252.

Parágrafo único. Na provisão de conexão à Internet, onerosa ou gratuita, é vedado monitorar, filtrar, analisar ou fiscalizar o conteúdo dos pacotes de dados, ressalvadas as hipóteses admitidas em lei.

Seção II

Da Guarda de Registros

Art. 10. A guarda e a disponibilização dos registros de conexão e de acesso a aplicações de Internet de que trata esta Lei devem atender à preservação da intimidade, vida privada, honra e imagem das partes direta ou indiretamente envolvidas.

$\S 1^{\circ}$ O provedor responsável pela guarda somente será obrigado a disponibilizar as informações que permitam a identificação do usuário mediante ordem judicial, na forma do disposto na Seção IV deste Capítulo.

$\S 2^{\circ}$ As medidas e procedimentos de segurança e sigilo devem ser informados pelo responsável pela provisão de serviços de conexão de forma clara e atender a padrões definidos em regulamento.

$\S 3^{\circ} \mathrm{A}$ violação do dever de sigilo previsto no caput sujeita o infrator às sanções cíveis, criminais e administrativas previstas em lei.

\section{Subseção I}

Da Guarda de Registros de Conexão

Art. 11. Na provisão de conexão à Internet, cabe ao administrador do sistema autônomo respectivo o dever de manter os 
Artigo original

Hegemonia - Revista Eletrônica de Relações Internacionais do Centro Universitário Unieuro

ISSN: $1809-1261$

UNIEURO, Brasília, número 10, 2012, pp. 158-252.

registros de conexão, sob sigilo, em ambiente controlado e de segurança, pelo prazo de um ano, nos termos do regulamento.

$\S 1^{\circ}$ A responsabilidade pela manutenção dos registros de conexão não poderá ser transferida a terceiros.

$\S 2^{\circ} \mathrm{A}$ autoridade policial ou administrativa poderá requerer cautelarmente a guarda de registros de conexão por prazo superior ao previsto no caput.

$\S 3^{\circ} \mathrm{Na}$ hipótese do $\S 2^{\circ}$, a autoridade requerente terá o prazo de sessenta dias, contados a partir do requerimento, para ingressar com o pedido de autorização judicial de acesso aos registros previstos no caput.

$\S 4^{\circ} \mathrm{O}$ provedor responsável pela guarda dos registros deverá manter sigilo em relação ao requerimento previsto no $\S 2^{\circ}$, que perderá sua eficácia caso o pedido de autorização judicial seja indeferido ou não tenha sido impetrado no prazo previsto no $\S 3^{\circ}$.

\section{Subseção II}

Da Guarda de Registros de Acesso a Aplicações de Internet

Art. 12. Na provisão de conexão, onerosa ou gratuita, é vedado guardar os registros de acesso a aplicações de Internet.

Art. 13. Na provisão de aplicações de Internet é facultado guardar os registros de acesso dos usuários, respeitado o disposto no art. $7^{\circ}$. 
Artigo original

Hegemonia - Revista Eletrônica de Relações Internacionais do Centro Universitário Unieuro

ISSN: $1809-1261$

UNIEURO, Brasília, número 10, 2012, pp. 158-252.

$\S 1^{\circ}$ A opção por não guardar os registros de acesso a aplicações de Internet não implica responsabilidade sobre danos decorrentes do uso desses serviços por terceiros.

$\S 2^{\circ}$ Ordem judicial poderá obrigar, por tempo certo, a guarda de registros de acesso a aplicações de Internet, desde que se tratem de registros relativos a fatos específicos em período determinado, ficando o fornecimento das informações submetido ao disposto na Seção IV deste Capítulo.

$\S 3^{\circ}$ Observado $\circ$ disposto no $\S 2^{\circ}$, a autoridade policial ou administrativa poderá requerer cautelarmente a guarda dos registros de aplicações de Internet, observados o procedimento e os prazos previstos nos $\S \S 3^{\circ}$ e $4^{\circ}$ do art. 11.

\section{Seção III}

Da Responsabilidade por Danos Decorrentes de Conteúdo Gerado por Terceiros

Art. 14. O provedor de conexão à Internet não será responsabilizado por danos decorrentes de conteúdo gerado por terceiros.

Art. 15. Salvo disposição legal em contrário, o provedor de aplicações de Internet somente poderá ser responsabilizado por danos decorrentes de conteúdo gerado por terceiros se, após ordem judicial específica, não tomar as providências para, no âmbito do seu serviço e 
Artigo original

Hegemonia - Revista Eletrônica de Relações Internacionais do Centro Universitário Unieuro

ISSN: $1809-1261$

UNIEURO, Brasília, número 10, 2012, pp. 158-252.

dentro do prazo assinalado, tornar indisponível o conteúdo apontado como infringente.

Parágrafo único. A ordem judicial de que trata o caput deverá conter, sob pena de nulidade, identificação clara e específica do conteúdo apontado como infringente, que permita a localização inequívoca do material.

Art. 16. Sempre que tiver informações de contato do usuário diretamente responsável pelo conteúdo a que se refere o art. 15, caberá ao provedor de aplicações de Internet informar-lhe sobre o cumprimento da ordem judicial.

\section{Seção IV}

Da Requisição Judicial de Registros

Art. 17. A parte interessada poderá, com o propósito de formar conjunto probatório em processo judicial cível ou penal, em caráter incidental ou autônomo, requerer ao juiz que ordene ao responsável pela guarda o fornecimento de registros de conexão ou de registros de acesso a aplicações de Internet.

Parágrafo único. Sem prejuízo dos demais requisitos legais, o requerimento deverá conter, sob pena de inadmissibilidade:

I - fundados indícios da ocorrência do ilícito;

II - justificativa motivada da utilidade dos registros solicitados para fins de investigação ou instrução probatória; e III - período ao qual se referem os registros. 
Artigo original

Hegemonia - Revista Eletrônica de Relações Internacionais do Centro Universitário Unieuro

ISSN: $1809-1261$

UNIEURO, Brasília, número 10, 2012, pp. 158-252.

Art. 18. Cabe ao juiz tomar as providências necessárias à garantia do sigilo das informações recebidas e à preservação da intimidade, vida privada, honra e imagem do usuário, podendo determinar segredo de justiça, inclusive quanto aos pedidos de guarda de registro.

\section{CAPÍTULO IV DA ATUAÇÃO DO PODER PÚBLICO}

Art. 19. Constituem diretrizes para a atuação da União, dos Estados, do Distrito Federal e dos Municípios no desenvolvimento da Internet no Brasil:

I - estabelecimento de mecanismos de governança transparentes, colaborativos e democráticos, com a participação dos vários setores da sociedade;

II - promoção da racionalização e da interoperabilidade tecnológica dos serviços de governo eletrônico, entre os diferentes Poderes e níveis da federação, para permitir o intercâmbio de informações e a celeridade de procedimentos;

III - promoção da interoperabilidade entre sistemas e terminais diversos, inclusive entre os diferentes níveis federativos e diversos setores da sociedade;

IV - adoção preferencial de tecnologias, padrões e formatos abertos e livres; 
Artigo original

Hegemonia - Revista Eletrônica de Relações Internacionais do Centro Universitário Unieuro

ISSN: $1809-1261$

UNIEURO, Brasília, número 10, 2012, pp. 158-252.

V - publicidade e disseminação de dados e informações públicos, de forma aberta e estruturada;

VI - otimização da infraestrutura das redes, promovendo a qualidade técnica, a inovação e a disseminação das aplicações de Internet, sem prejuízo à abertura, à neutralidade e à natureza participativa;

VII - desenvolvimento de ações e programas de capacitação para uso da Internet;

VIII - promoção da cultura e da cidadania; e

IX - prestação de serviços públicos de atendimento ao cidadão de forma integrada, eficiente, simplificada e por múltiplos canais de acesso.

Art. 20. Os sítios e portais de Internet de entes do Poder Público devem buscar:

I - compatibilidade dos serviços de governo eletrônico com diversos terminais, sistemas operacionais e aplicativos para seu acesso;

II - acessibilidade a todos os interessados, independentemente de suas capacidades físico-motoras, perceptivas, culturais e sociais, resguardados os aspectos de sigilo e restrições administrativas e legais;

III - compatibilidade tanto com a leitura humana quanto com o tratamento automatizado das informações;

IV - facilidade de uso dos serviços de governo eletrônico; e $\mathrm{V}$ - fortalecimento da participação social nas políticas públicas. 
Artigo original

Hegemonia - Revista Eletrônica de Relações Internacionais do Centro Universitário Unieuro

ISSN: $1809-1261$

UNIEURO, Brasília, número 10, 2012, pp. 158-252.

Art. 21. O cumprimento do dever constitucional do Estado na prestação da educação, em todos os níveis de ensino, inclui a capacitação, integrada a outras práticas educacionais, para o uso seguro, consciente e responsável da Internet como ferramenta para o exercício da cidadania, a promoção de cultura e o desenvolvimento tecnológico.

Art. 22. As iniciativas públicas de fomento à cultura digital e de promoção da Internet como ferramenta social devem:

I - promover a inclusão digital;

II - buscar reduzir as desigualdades, sobretudo entre as diferentes regiões do País, no acesso às tecnologias da informação e comunicação e no seu uso; e III - fomentar a produção e circulação de conteúdo nacional.

Art. 23. O Estado deve, periodicamente, formular e fomentar estudos, bem como fixar metas, estratégias, planos e cronogramas referentes ao uso e desenvolvimento da Internet no País.

\section{CAPÍTULO V DISPOSIÇÕES FINAIS}

Art. 24. A defesa dos interesses e direitos estabelecidos nesta Lei poderá ser exercida em juízo, individual ou coletivamente, na forma da lei. 
Artigo original

Hegemonia - Revista Eletrônica de Relações Internacionais do Centro Universitário Unieuro

ISSN: $1809-1261$

UNIEURO, Brasília, número 10, 2012, pp. 158-252.

Art. 25. Esta Lei entra em vigor sessenta dias após a data de sua publicação.

Brasília, 
Artigo original

Hegemonia - Revista Eletrônica de Relações Internacionais do Centro Universitário Unieuro

ISSN: $1809-1261$

UNIEURO, Brasília, número 10, 2012, pp. 158-252.

EMI No $00086-\mathrm{MJ} / \mathrm{MP} / \mathrm{MCT} / \mathrm{MC}$

Brasília, 25 de abril de 2011

Excelentíssima Senhora Presidenta da República,

Submetemos à elevada consideração de Vossa Excelência o anexo anteprojeto de lei que estabelece princípios, garantias, direitos e deveres para o uso da rede mundial de computadores no país, e dá outras providências. Tal projeto foi construído em conjunto com a sociedade, em processo que ficou conhecido sob a denominação de Marco Civil da Internet.

2. Dados recentes da Pesquisa Nacional por Amostra de Domicílios PNAD referente ao ano de 2009 realizada pelo Instituto Brasileiro de Geografia e Estatística (IBGE) apontam a existência de sessenta e oito milhões de internautas, com taxa de crescimento de mais de um milhão a cada três meses. Ao mesmo tempo em que empolgam, esses números expressam a dimensão dos diversos desafios para que a Internet realize seu potencial social. Um desses desafios é harmonizar a interação entre o Direito e a chamada cultura digital, superando uma série de obstáculos críticos, presentes tanto nas instituições estatais quanto difusos na sociedade.

3. No âmbito legislativo, diversos projetos de lei tramitam desde 1995, ano do início da oferta comercial de conexões no país. No entanto, passados quinze anos, ainda não existe um texto de lei específico para 
Artigo original

Hegemonia - Revista Eletrônica de Relações Internacionais do Centro Universitário Unieuro

ISSN: $1809-1261$

UNIEURO, Brasília, número 10, 2012, pp. 158-252.

o ambiente cibernético que garanta direitos fundamentais e promova o desenvolvimento econômico e cultural.

4. Para o Poder Judiciário, a ausência de definição legal específica, em face da realidade diversificada das relações virtuais, tem gerado decisões judiciais conflitantes, e mesmo contraditórias. Não raro, controvérsias simples sobre responsabilidade civil obtêm respostas que, embora direcionadas a assegurar a devida reparação de direitos individuais, podem, em razão das peculiaridades da Internet, colocar em risco as garantias constitucionais de privacidade e liberdade de expressão de toda a sociedade.

5. Também a Administração Pública é submetida a dificuldades para promover o desenvolvimento da Internet, em temas tão variados como infraestrutura e padrões de interoperabilidade. Diversas políticas públicas de governo bem sucedidas ainda carecem de um amparo legal integrado para sua adoção como políticas de Estado, que permitam, nos diversos níveis federativos, uma abordagem de longo prazo para cumprir o objetivo constitucional de redução das desigualdades sociais e regionais.

6. Por fim, a crescente difusão do acesso enseja novos contratos jurídicos, para os quais a definição dos limites fica a cargo dos próprios contratantes, sem a existência de balizas legais. A seguir essa lógica, a tendência do mercado é a de que os interesses dos agentes de maior 
Artigo original

Hegemonia - Revista Eletrônica de Relações Internacionais do Centro Universitário Unieuro

ISSN: $1809-1261$

UNIEURO, Brasília, número 10, 2012, pp. 158-252.

poder econômico se imponham sobre as pequenas iniciativas, e que as pretensões empresariais enfraqueçam os direitos dos usuários.

7. Os riscos são, portanto, a) da aprovação desarticulada de propostas normativas especializadas, que gerem divergência e prejudiquem um tratamento harmônico da matéria; b) de prejuízos judiciais sensíveis, até que a jurisprudência se adeque às realidades da sociedade da informação; c) de desencontros ou mesmo omissões nas políticas públicas; e d) de violação progressiva de direitos dos usuários pelas práticas e contratos livremente firmados.

8. Esse quadro de obstáculos faz oportuna a aprovação de uma lei que, abordando de forma transversal a Internet, viabilize ao Brasil o início imediato de um melhor diálogo entre o Direito e a Internet. Uma norma que reconheça a pluralidade das experiências e que considere a riqueza e a complexidade dessa nova realidade.

9. Com esse propósito, a Secretaria de Assuntos Legislativos do Ministério da Justiça - SAL/MJ, em parceria com o Centro de Tecnologia e Sociedade da Escola de Direito da Fundação Getúlio Vargas do Rio de Janeiro, desenvolveu a iniciativa denominada Marco Civil da Internet no Brasil, a fim de construir, de forma colaborativa, um anteprojeto de lei que estabelecesse princípios, garantias e direitos dos usuários de Internet. A proposta delimita deveres e responsabilidades a serem exigidos dos prestadores de serviços e define o papel a ser exercido 
Artigo original

Hegemonia - Revista Eletrônica de Relações Internacionais do Centro Universitário Unieuro

ISSN: $1809-1261$

UNIEURO, Brasília, número 10, 2012, pp. 158-252.

pelo poder público em relação ao desenvolvimento do potencial social da rede.

10. Com vistas ao diálogo entre normas jurídicas e a rede mundial de computadores, partiu-se de duas óbvias inspirações: o texto constitucional e o conjunto de recomendações apresentadas pelo Comitê Gestor da Internet no Brasil - CGI.br - no documento "Princípios para a governança e uso da Internet" (Resolução CGI.br/RES/2009/003/P). Para o seu desenvolvimento, o projeto se valeu de inovador debate aberto a todos os internautas.

11. Uma discussão ampla foi realizada com a sociedade pela própria Internet, entre outubro de 2009 e maio de 2010, por meio de um blog hospedado na plataforma Cultura Digital (uma rede social mantida pelo Ministério da Cultura e pela Rede Nacional de Ensino e Pesquisa RNP). Esse processo de participação popular resultou em mais de dois mil comentários diretos, incontáveis manifestações sobre o "\#marcocivil" em ferramentas virtuais, como os microblogs Identi.ca e Twitter, além de dezenas de documentos institucionais, oriundos do Brasil e do exterior.

12. A dinâmica adotada teve como meta usar a própria Internet para, desde já, conferir mais densidade à democracia. Por meio da abertura e da transparência, permitiu-se a franca expressão pública de todos os grupos sociais, por meio de um diálogo civilizado e construtivo. 
Artigo original

Hegemonia - Revista Eletrônica de Relações Internacionais do Centro Universitário Unieuro

ISSN: $1809-1261$

UNIEURO, Brasília, número 10, 2012, pp. 158-252.

13. Resultado desse processo, o anteprojeto ora proposto se estrutura em cinco capítulos: disposições preliminares, direitos e garantias do usuário, provisão de conexão e de aplicações de Internet, atuação do poder público e disposições finais.

14. No primeiro capítulo são indicados os fundamentos, princípios e objetivos do marco civil da internet, além da definição de conceitos e de regras de interpretação. Entre os fundamentos, enumeram-se elementos da realidade jurídica do uso da Internet que servem de pressupostos para a proposta. Por sua vez, entre os princípios figuram os pontos norteadores que devem sempre informar a aplicação do direito em relação à matéria. Já no âmbito dos objetivos, apontam-se as finalidades a serem perseguidas de forma permanente, não apenas pelo Estado, mas por toda a sociedade.

15. No capítulo sobre os direitos e garantias do usuário, o acesso à internet é reconhecido como um direito essencial ao exercício da cidadania. Ainda são apontados direitos específicos a serem observados, tais como a inviolabilidade e o sigilo das comunicações pela internet e a não suspensão da conexão.

16. No terceiro capítulo, ao tratar da provisão de conexão e de aplicações de internet, o anteprojeto versa sobre as questões como: o tráfego de dados, a guarda de registros de conexão à Internet, a guarda de registro de acesso a aplicações na rede, a responsabilidade por danos decorrentes de conteúdo gerado por terceiros e a requisição 
Artigo original

Hegemonia - Revista Eletrônica de Relações Internacionais do Centro Universitário Unieuro

ISSN: $1809-1261$

UNIEURO, Brasília, número 10, 2012, pp. 158-252.

judicial de registros. As opções adotadas privilegiam a responsabilização subjetiva, como forma de preservar as conquistas para a liberdade de expressão decorrentes da chamada Web 2.0, que se caracteriza pela ampla liberdade de produção de conteúdo pelos próprios usuários, sem a necessidade de aprovação prévia pelos intermediários. A norma mira os usos legítimos, protegendo a privacidade dos usuários e a liberdade de expressão, adotando como pressuposto o princípio da presunção de inocência, tratando os abusos como eventos excepcionais.

17. No capítulo referente às atribuições do Poder Público, fixam-se diretrizes para a atuação da União, dos Estados, do Distrito Federal e dos Municípios no desenvolvimento da Internet no Brasil, além de regras para os sítios públicos, para a Educação, para o fomento cultural e para a avaliação constante do resultado das políticas públicas. Confere-se à Administração Pública um parâmetro para o melhor cumprimento dos objetivos do Marco Civil.

18. Finalmente, o último capítulo prevê expressamente a possibilidade de que a defesa dos interesses e direitos pertinentes ao uso da Internet seja exercida de forma individual ou coletiva, na forma da Lei. 19. No panorama normativo, o anteprojeto representa um primeiro passo no caminho legislativo, sob a premissa de que uma proposta legislativa transversal e convergente possibilitará um posicionamento futuro mais adequado sobre outros importantes temas relacionados à internet que ainda carecem de harmonização, como a proteção de 
Artigo original

Hegemonia - Revista Eletrônica de Relações Internacionais do Centro Universitário Unieuro

ISSN: $1809-1261$

UNIEURO, Brasília, número 10, 2012, pp. 158-252.

dados pessoais, o comércio eletrônico, os crimes cibernéticos, o direito autoral, a governança da internet e a regulação da atividade dos centros públicos de acesso à internet, entre outros. A despeito das mencionadas lacunas normativas, a solução que se submete à avaliação de Vossa Excelência faz jus ao potencial criativo e inovador característico do povo brasileiro, alçando o país à posição de protagonista mundial na garantia das novas liberdades da cultura digital.

Ante todo o exposto, Senhora Presidenta, a proposta que institui o marco civil da internet no Brasil deve, a nosso ver, ser incorporada ao direito positivo pátrio, a fim de estabelecer princípios, garantias, direitos e deveres para o uso da rede mundial de computadores no país.

Respeitosamente,

Assinado por: José Eduardo Martins Cardozo, Miriam Aparecida Belchior, Aloizio Mercadante Oliva e Paulo Bernardo Silva 
Artigo original

Hegemonia - Revista Eletrônica de Relações Internacionais do Centro Universitário Unieuro

ISSN: $1809-1261$

UNIEURO, Brasília, número 10, 2012, pp. 158-252.

ANEXO B - PROJETOS DE LEI SOBRE DIREITO VIRTUAL EM TRAMITAÇÃO

PL 3175/2012 - Autor: Edson Pimenta - PSD /BA - Ementa: Dispõe sobre o Estatuto da Internet no Brasil. Explicação da Ementa: Altera o Decreto-Lei no 2.848, de 1940 e a Lei n 9.296, de 1996.

PL 3761/2012 - Autor: Edson Pimenta - PSD /BA - Ementa: Dispõe sobre os meios de prova admitidos no processo cível e penal, quando a lide envolver o uso de sistema eletrônico, digital ou similares, de rede de computadores, ou que sejam praticadas contra dispositivos de comunicação ou sistemas informatizados e similares. Explicação da Ementa: Altera a Lei no 5.869, de 1973 e o Decreto-Lei no 3.689, 1941.

PL 3124/2012 - Autor: Luciano Castro - PR /RR - Ementa: Dispõe sobre os meios de prova admitidos no processo cível e penal, quando a lide envolver o uso de sistema eletrônico, digital ou similares, de rede de computadores, ou que sejam praticadas contra dispositivos de comunicação ou sistemas informatizados e similares. Explicação da Ementa: Altera a Lei no 5.869, de 1973 e o Decreto-Lei no 3.689, de 1941.

PL 3095/2012 - Autor: Dimas Fabiano - PP /MG - Ementa: Dispõe sobre a obrigatoriedade de fornecimento de manutenção corretiva gratuita no provimento de serviços de acesso à Internet em Banda Larga.

PL 3033/2011 - Autor: Aguinaldo Ribeiro - PP /PB - Ementa: Modifica os arts. 138 a 140 do Decreto-lei no 2.848, de 7 de dezembro de 1940 - Código Penal. Explicação da Ementa: Altera as penas dos crimes contra a honra.

PL 2690/2011 - Autor: Pastor Marco Feliciano - PSC /SP - Ementa: Dispõe sobre o acesso a sítios com conteúdo adulto na internet e dá outras providências.

PL 2552/2011- Autor: Ronaldo Fonseca - PR /DF - Ementa: Altera a Lei no 8.069, de 13 de julho de 1990, que dispõe sobre o Estatuto da Criança e do Adolescente e dá outras providências. Explicação da Ementa: Conteúdo impróprio ou inadequado a crianças e adolescentes em websites deverá ser visto e acessado apenas com senha de usuário assinante, maior de 18 anos, passando tal ato a ser penalizado, caso descumprido. 
Artigo original

Hegemonia - Revista Eletrônica de Relações Internacionais do Centro Universitário Unieuro

ISSN: $1809-1261$

UNIEURO, Brasília, número 10, 2012, pp. 158-252.

PL 2126/2011 - Autor: Poder Executivo - Ementa: Estabelece princípios, garantias, direitos e deveres para o uso da Internet no Brasil.

PL 1961/2011 - Autor: Liliam Sá - PR /RJ - Ementa: Dispõe sobre a interceptação de comunicações na Internet.

PL 1880/2011 - Autor: Jonas Donizette - PSB /SP - Ementa: Fixa requisitos para que provedores hospedem e conectem sítios (sites) de compra à rede mundial de computadores (internet) e dá outras providências.

PL 1468/2011 - Autor: Ângelo Agnolin - PDT /TO - Ementa: Acrescenta os $\S \S 5^{\circ}$ e $6^{\circ}$

ao art. 20 da Lei no 7.716, de 15 de janeiro de 1989, que "define os crimes resultantes de preconceito de raça ou de cor", para estabelecer punição aos crimes resultantes de discriminação ou preconceito de raça, cor, etnia, religião ou procedência nacional cometidos por meio da rede mundial de computadores - Internet; para revogar o inciso III do $\S 30$ do art. 20 da Lei no 7.716, de 15 de janeiro de 1989, que "define os crimes resultantes de preconceito de raça ou de cor"; e para criar obrigatoriedade de veiculação de mensagem educativa entre as cláusulas constantes dos termos de aceitação exibidos durante 0 cadastro de novos usuários em blogs, redes sociais, wikis ou qualquer outro dispositivo que permita a publicação de informações por usuários da rede mundial de computadores - Internet.

PL 1172/2011 - Autor: Luiz Otavio - PMDB /PA - Ementa: Assegura ao usuário do serviço de correio eletrônico o direito ao sigilo e à integralidade dos dados, bem como à portabilidade do conteúdo das mensagens.

PL 642/2011 - Autor: Ratinho Junior - PSC /PR - Ementa: Obriga os estabelecimentos que locam ou disponibilizam terminais de computadores a manterem cadastro de identificação de seus usuários com imagem e documentos oficiais. Explicação da Ementa: Estabelecimentos conhecidos como "Lan House", "Cybercafé", Cybernet", "Cyberoffice".

PL 7311/2010 - Autor: Eduardo da Fonte - PP /PE - Ementa: Dispõe sobre os sítios da Internet no Brasil.

PL 7270/2010 - Autor: Wellington Fagundes - PR /MT - Ementa:

Dispõe sobre a obrigatoriedade de manutenção de registro dos usuários de "lan houses" e estabelecimentos similares que provêm 
Artigo original

Hegemonia - Revista Eletrônica de Relações Internacionais do Centro Universitário Unieuro

ISSN: $1809-1261$

UNIEURO, Brasília, número 10, 2012, pp. 158-252.

acesso à internet.

PL 7131/2010 - Autor: Gerson Peres - PP /PA - Ementa: Dispõe sobre a responsabilidade dos proprietários e autores de blogues e mecanismos similares.

PL 6527/2009 - Autor: Silas Brasileiro - PMDB /MG - Ementa: Dispõe a suspensão do acesso à Internet de quem utilizar este meio de comunicação para prática ou incentivo à prática de pedofilia e atividades afins.

PL 6357/2009 - Autor: SENADO FEDERAL - GERSON CAMATA - PMDB /ES - Ementa: Obriga os estabelecimentos de locação de terminais de computadores a manterem cadastro de seus usuários. Explicação da Ementa: Estabelecimentos conhecidos como "Lan House", "Cybercafé", Cybernet", "Cyberoffice".

PL 5298/2009 - Autor: Jefferson Campos - PTB /SP - Ementa: Dispõe sobre a identificação dos usuários dos serviços de correio eletrônico.

PL 5185/2009 - Autor: Fábio Faria - PMN /RN - Ementa: Estabelece a obrigatoriedade de cadastramento e de identificação eletrônica para fins de acesso à rede mundial de computadores, e de manutenção dos dados informáticos pelo período de 2 (dois) anos para fins de investigação criminal ou instrução de processo processual penal.

PL 4424/2008 - Autor: Nelson Goetten - PR /SC - Ementa: Dispõe sobre o Estatuto da Internet no Brasil. Explicação da Ementa: Altera o Decreto-Lei no 2.848, de 1940 e a Lei no 9.296, de 1996.

PL 2957/2008 - Autor: Nelson Proença - PPS /RS - Ementa: Dispõe sobre a privacidade de dados e a relação entre usuários, provedores e portais em redes eletrônicas.

PL 169/2007 - Autor: Professora Raquel Teixeira - PSDB /GO Ementa: Dispõe sobre o envio de mensagem não solicitada por meio de redes de computadores destinadas ao uso do público. Explicação da Ementa: Dispõe sobre as limitações ao envio de mensagem não solicitada - uso de "Spam".

PL 5009/2005 - Autor: Cabo Júlio - PMDB /MG - Ementa: Obriga as empresas de locação de terminais de computadores a manter cadastro de seus usuários e dá outras providências. Explicação da Ementa: Disciplinando o funcionamento dos chamados "cyber - cafe" ou "Ian house".

PL 4562/2004 - Autor: Silas Brasileiro - PMDB /MG - Ementa: Dispõe sobre a identificação de assinantes de serviços de correio eletrônico 
Artigo original

Hegemonia - Revista Eletrônica de Relações Internacionais do Centro Universitário Unieuro

ISSN: $1809-1261$

UNIEURO, Brasília, número 10, 2012, pp. 158-252.

em redes de computadores destinadas ao uso público, inclusive a Internet. Explicação da Ementa: Cria mecanismos para coibir o SPAM, mensagens não solicitadas.

PL 4144/2004 - Autor: Marcos Abramo - PFL /SP - Ementa: Altera a Lei no 8.069, de 13 de julho de 1990, a Lei no 9.296, de 24 de julho de 1996, e o Decreto-Lei no 2.848, de 7 de dezembro de 1940, e dá outras providências. Explicação da Ementa: Tipifica o crime informático, praticado por "hackers", inclui os crimes de sabotagem, falsidade e fraude informática; autoriza as autoridades a interceptarem dados dos provedores e prevê a pena de reclusão para quem armazena, em meio eletrônico, material pornográfico, envolvendo criança e adolescente.

PL 3301/2004 - Autor: Marcos Abramo - PFL /SP - Ementa: Dispõe sobre normas de acesso à Internet.

PL 2196/2003 - Autor: Waldemir Moka - PMDB /MS - Ementa: Dispõe sobre a divulgação de mensagens pelos usuários de provedores na Internet e demais redes de computadores abertas ao uso do público. Explicação da Ementa: Estabelece que o provedor hospedeiro ou titular de lista aberta de discussão, debate em salas de "chat" e votação será co-responsável pelo conteúdo da mensagem veiculada, pode exercer o papel de moderador, restringe as mensagens que considerar inoportunas ou cujo autor não possa ser identificado.

PL 1256/2003 - Autor: Takayama - PSB /PR - Ementa: Estabelece obrigatoriedade aos provedores da rede internet que operam no Brasil, a identificação para participantes com acesso a salas de encontros virtuais de conteúdo sexual e restringe a veiculação e troca de imagens de conteúdo sexual.

PL 480/2003 - Autor: Pompeo de Mattos - PDT /RS - Ementa: Dispõe sobre o cadastramento dos usuários de serviços de Internet e disponibilização de dados à autoridade policial e dá outras providências.

PL 18/2003 - Autor: Iara Bernardi - PT /SP - Ementa: Veda o anonimato dos responsáveis por páginas na Internet e endereços eletrônicos registrados no País.

PL 7461/2002 - Autor: Eni Voltolini - PPB /SC - Ementa: Dispõe sobre a obrigatoriedade dos provedores de acesso a Internet manterem cadastro de usuários e registro de transações.

PL 6557/2002 - Autor: Valdemar Costa Neto - PL /SP - Ementa: 
Artigo original

Hegemonia - Revista Eletrônica de Relações Internacionais do Centro Universitário Unieuro

ISSN: $1809-1261$

UNIEURO, Brasília, número 10, 2012, pp. 158-252.

Estabelece obrigatoriedade de identificação para participantes com acesso a salas de encontros virtuais e troca de imagens na Rede Mundial de Computadores, Internet. Explicação da Ementa: Identificação dos usuários das salas de "chat", bate-papo ou encontro virtual e troca de imagens na INTERNET.

PL 5977/2001 - Autor: Divaldo Suruagy - PST /AL - Ementa: Dispõe sobre a disciplina de acesso e uso dos serviços da INTERNET pelos estabelecimentos de ensino e órgãos públicos em geral.

PL 5403/2001 - Autor: Senado Federal - LUIZ ESTEVÃO - PMDB /DF Ementa: Dispõe sobre o acesso a informações da Internet, e dá outras providências.

PL 5403/2001- Substitutivo - Autor: Paulo Marinho - PL /MA - Ementa: Estabelece normas para a prestação de serviço de acesso à Internet. PL 4972/2001 - Autor: José Carlos Coutinho - PFL /RJ - Ementa: Dispõe sobre o acesso à informação da internet, e dá outras providências. Explicação da Ementa: Exige que os provedores de acesso a Internet realizem o cadastro das contas dos usuários, de forma a permitir a identificação e definir a política de uso do serviço prestado.

PL 3891/2000 - Autor: Julio Semeghini - PSDB /SP - Ementa: Dispõe sobre o registro de usuários pelos provedores de serviços de acesso a redes de computadores, inclusive à Internet. Explicação da Ementa: Obriga os provedores de serviços da Internet a manterem registros de seus usuários, e dados referentes a cada transação atendida pelo provedor, para solucionar o problema da identificação do usuário em caso de utilização ilicita da rede, cometidas, em geral, por hackers .

PL 3303/2000 - Autor: Antonio Feijão - PST /AP - Ementa: Dispõe sobre normas de operação e uso da Internet no Brasil.

PL 3016/2000 - Autor: Antonio Carlos Pannunzio - PSDB /SP - Ementa: Dispõe sobre o registro de transações de acesso a redes de 